D.O.I.: $10.3895 / \mathrm{S} 1808-04482007000300007$

\title{
GRANDE EMPRESA INDUSTRIAL, REESTRUTURAÇÃO PRODUTIVA E A DINÂMICA RECENTE DO EMPREGO FORMAL NO BRASIL
}

\section{GREAT INDUSTRIAL COMPANY, PRODUCTIVE RESTRUCTURING AND THE RECENT DYNAMIC OF THE FORMAL JOB IN BRAZIL}

\author{
Tiago Oliveira ${ }^{1}$; Marcelo Weishaupt Proni ${ }^{2}$ \\ ${ }^{1}$ Mestre em Economia Social e do Trabalho pela Unicamp e Técnico do Departamento Intersindical \\ de Estatísticas e Estudos Sócio-Econômicos - DIEESE tiago@dieese.org.br. \\ ${ }^{2}$ Professor do Instituto de Economia da Unicamp mwproni@eco.unicamp.br
}

\begin{abstract}
Resumo
O presente artigo propõe-se a discutir os impactos da reestruturação produtiva sobre o nível de emprego e os salários nas grandes empresas industriais, assim como verificar se mudou a distribuição regional do emprego industrial e o perfil dos empregados do setor. Nesse sentido, podem ser visualizados dois subperiodos bastante distintos. Na década de 1990 houve uma perda na participação relativa da indústria de transformação no emprego formal, em decorrência, sobretudo, do enxugamento promovido pelos estabelecimentos de grande porte. Nos anos 2000, por seu turno, registra-se uma inflexão: os grandes estabelecimentos da indústria voltam a gerar postos de trabalho e a participação do setor se estabiliza. Em termos regionais, o investimento das grandes empresas tem privilegiado regiões menos tradicionais em busca de benefícios fiscais $e$ redução no custo do trabalho, sendo a região sul a grande beneficiária desse movimento de desconcentração industrial iniciado nos anos 1990. No que se refere aos impactos causados pela reestruturação da grande empresa industrial sobre o perfil da força de trabalho, os resultados apontam mudanças importantes, mas também continuidade de velhas características. Em suma, as transformações que vêm ocorrendo não têm se traduzido em melhores condições de emprego e renda para a maioria da classe operária nacional, nem contribuido para uma maior eqüidade salarial entre as diversas regiões brasileiras.
\end{abstract}

Palavras-chave: reestruturação produtiva; emprego; grande empresa.

\section{Introdução}

As mudanças que vêm ocorrendo há mais de três décadas no capitalismo têm impactado diretamente nas estratégias das grandes empresas, especialmente naquelas do setor industrial. Entre tais mudanças, destacam-se aquelas que caracterizam o que muitos autores denominaram como “reestruturação produtiva" (PRONI e POCHMANN, 2006; OLIVEIRA, 2007).

No período considerado como o mais virtuoso do capitalismo - a partir do imediato pósguerra até o início dos anos 1970 -, fontes energéticas extremamente baratas, demanda agregada aquecida, salários reais em elevação (ao passo do crescimento da produtividade), taxas de juros 
reduzidas, intensa inovação tecnológica e gasto público crescente no campo militar e na área social, asseguravam a lucratividade dos negócios capitalistas e a ampliação do bem-estar social. Foi uma época muito favorável para as grandes corporações industriais, ainda que houvesse extensas regulamentações públicas sobre a contratação, o uso e a remuneração da força de trabalho, bem como foi um período muito favorável aos trabalhadores da indústria, ainda que predominasse uma organização rígida da produção e do trabalho, herança de uma concepção taylorista-fordista de administração empresarial.

Todavia, a ruptura do pacto político em prol do crescimento econômico e do pleno emprego, paralelamente ao enfraquecimento do legado keynesiano, instaurou uma ordem econômica marcada pela hegemonia de um capitalismo "desregulado", com clara predominância da esfera financeira. Crescimento econômico lento, custo energético elevado (especialmente após os choques do petróleo durante a década de 1970), altas taxas de juros e desemprego em níveis inéditos nas principais nações industrializadas colocaram em xeque o paradigma de conduta da grande empresa da era fordista. Com isso, a produção homogênea em grande escala, verticalizada, assentada numa organização produtiva rigidamente disposta no formato de linhas de montagens e valendo-se de uma mão-de-obra extremamente especializada se tornou um verdadeiro obstáculo para a atividade empresarial frente às mudanças pelas quais vem passando o capitalismo desde o colapso da "ordem keynesiana".

A estratégia mais comum adotada foi enxugar e flexibilizar o processo produtivo, procurando externalizar aquelas atividades consideradas acessórias ao objetivo central das empresas. Para tanto, disseminaram-se pelos países capitalistas do ocidente as práticas organizacionais de origem japonesa (também conhecidas como toyotismo), a exemplo do just-intime/kanban, da terceirização de atividades, da simplificação das estruturas hierárquicas, do downsizing, entre outras. Paralelamente, promoveu-se a incorporação de máquinas e equipamentos flexíveis de base microeletrônica.

Tais mudanças impactaram diretamente sobre o conjunto da força de trabalho ligado a essas empresas. A partir de então, a mão-de-obra teve que se tornar multifuncional, organizar-se em células de equipe, trabalhar no regime de banco de horas, introduzir a preocupação com a qualidade do produto e dos processos no seu dia-a-dia (inclusive para aqueles trabalhadores do "chão-defábrica"), ampliar a parcela variável da remuneração, etc. Nesse cenário, o contrato padrão de emprego vigente na era fordista (o standard employment relationship), com suas regulamentações sobre a jornada de trabalho, a remuneração e a utilização da força de trabalho, passou a sofrer um ataque frontal, ao passo que foram estimuladas novas formas de regulação da relação capital/trabalho, a exemplo dos contratos de trabalho temporários ou em tempo parcial e das jornadas de trabalho moduladas. 
No entanto, o grande salto promovido pela reestruturação produtiva de caráter toyotista, em relação ao fordismo, foi a captura da subjetividade dos trabalhadores. Ou seja, as atuais transformações produtivas e organizacionais têm como um dos seus principais intuitos difundir a idéia de que os trabalhadores são, antes de tudo, "parceiros" do negócio e que, portanto, uma postura combativa por parte destes só traria prejuízos para a organização e, em ultima instância, para os próprios trabalhadores (ALVES, 2000).

Do ponto de vista empresarial, a idéia era atrelar ao máximo a força de trabalho às flutuações econômicas, aguçadas sobremaneira com a crescente desregulamentação do capital; ou seja, objetivava-se transformar, na medida do possível, os custos até então fixos em custos variáveis. Além disso, tornou-se imperioso, particularmente para as grandes empresas, reorientar a organização do processo produtivo em escala global, buscando as tradicionais vantagens comparativas proporcionadas pelos diversos países, mas também novas economias de escala, melhores práticas de produção que possam ser compartilhadas pelas diversas unidades da empresa, uma maior diferenciação de produtos e serviços possibilitados pela posição de player global e uma pulverização dos altos custos envolvidos nas tecnologias patenteadas (PORTER, 1986). Em decorrência, surge a grande empresa no formato de rede capaz de obter espaços até então pouco explorados de redução de custos. Ademais, vale lembrar que a organização em rede das grandes corporações tem moldado uma nova divisão internacional do trabalho marcada pela concentração nos países avançados das fases de concepção e design, ao passo que são relegadas para os países subdesenvolvidos as tarefas de fabricação e montagem dos produtos (PORTER, 1999; CARLEIAL, 2004; MARQUES, 2002).

No Brasil, a grande empresa somente experimentou de modo mais intenso mudanças semelhantes às verificadas nos países desenvolvidos a partir dos anos 1990 ${ }^{1}$. Antes disso, uma economia bastante protegida da concorrência externa e com elevadas reservas de mercado mostrava-se pouca propensa a grandes mudanças nas práticas gerenciais e nas tecnologias utilizadas. Os primeiros sinais nesse sentido, portanto, só começaram a surgir nos anos 1980 do século passado a reboque do ajuste econômico vivido naquele momento em prol de uma economia dirigida para gerar superávits na balança comercial. No entanto, a plenitude das transformações

\footnotetext{
${ }^{1}$ É preciso ter em mente que "grande empresa" no Brasil, quase sempre, reúne atributos bastante distintos aos verificados nos países mais avançados. Desse ponto de vista, podemos destacar: i) as diferenças em termos do ambiente macroeconômico no qual se inserem as grandes empresas: desde a moeda, passando pelo grau de heterogeneidade da estrutura produtiva, até a vulnerabilidade externa, só para citar alguns exemplos; ii) o próprio poder de mercado da grande empresa no Brasil é bastante inferior em comparação ao encontrado nos países desenvolvidos; iii) poucas grandes empresas no Brasil possuem uma autonomia tecnológica similar à existente nas congêneres estrangeiras, limitando sobremaneira a inovação no parque produtivo brasileiro; iv) além disso, o forte elo existente nos países avançados entre grande empresa, Estado e sistema financeiro (bancos e mercado de capitais) nem de longe se assemelha ao que ocorre com a grande empresa no Brasil, onde o Estado perdeu a capacidade de planejamento a longo prazo e as linhas de financiamento ao setor produtivo são escassas, de prazo insuficiente e com custo exorbitante; por fim, v) vale destacar o grau que assumiu a financeirização da riqueza por aqui, com poucos paralelos no mundo (vide o fato de determos a maior taxa real de juros entre as economias minimamente organizadas).
} 
produtivas só apareceu na década de 1990, no rastro da abertura comercial e financeira combinada com elevadas taxas de juros e sobrevalorização cambial.

Diante desse quadro, registrou-se um aumento expressivo dos investimentos externos diretos no País, boa parte deles em decorrência de mudanças patrimoniais - leia-se, privatizações e aquisições ou fusões -, o que contribuiu sobremaneira para a desnacionalização do parque produtivo brasileiro (GONÇALVES, 1999).

Foi a partir daí que se acelerou a difusão das práticas inspiradas no modelo japonês de organização da produção e do trabalho com destaque para o just-in-time/kaban, o controle da qualidade como um valor central no processo produtivo, a terceirização de atividades, a remuneração variável, o trabalho em equipe e pluriespecializado, o banco de horas, entre outras inovações.

Ademais, não podemos esquecer que essas mudanças nos anos 1990 ocorreram dentro de um cenário de taxas de crescimento econômico bastante modestas, de taxas de desemprego alarmantes e de uma informalização e precarização crescente das relações de trabalho, no rastro das reformas realizadas no marco regulatório trabalhista do País (PRONI e HENRIQUE, 2003).

Nesse contexto de primazia das políticas econômicas neoliberais, a localização das empresas industriais ao longo do território nacional durante os anos 1990 seguiu seu curso sem o amparo de qualquer política regional de desenvolvimento articulada pelo Estado brasileiro. Aliás, há uma grande controvérsia a respeito da continuidade ou não da desconcentração espacial da indústria brasileira. Para Pacheco (1996; 1999), a desconcentração continua ao longo dos anos 1990 com perdas mais significativas para a região metropolitana de São Paulo e para o estado do Rio de Janeiro, ao passo que: 1) aumenta a heterogeneidade interna das regiões brasileiras com o surgimento de "ilhas de produtividade"; 2) cresce mais rapidamente, em termos relativos, as antigas periferias nacionais; e 3) aumenta a importância das cidades médias. Nessa visão, portanto, o desenvolvimento econômico recente, em termos espaciais, tem sido marcado por uma crescente fragmentação e heterogeneidade. Por outro lado, para Cano (1997) os anos 1990 marcam uma inflexão do processo de desconcentração industrial expresso não só pela desaceleração desse fenômeno, mas até mesmo por uma suave reconcentração, estimulada pela abertura comercial.

Ainda nesse sentido, cabe chamar a atenção para a importância assumida nos anos 1990 pela guerra fiscal entre os governos estaduais (e até mesmo entre municípios) na atração de novos investimentos, sobretudo os realizados pelas empresas transnacionais. Com tais investimentos, que já traziam embutida a modernização tecnológica e organizacional, muitos acreditavam que fosse possível dirimir as enormes desigualdades na estrutura produtiva e de renda entre as diversas regiões brasileiras. 
Contribuiu para tanto o fato de algumas regiões de industrialização mais antiga (brownfields) terem se tornado menos atraentes para os novos investimentos: os menores custos do trabalho e a existência de sindicatos mais frágeis nas áreas de industrialização mais recentes, a redução do gap educacional entre as regiões brasileiras e a deterioração da infra-estrutura nas regiões industriais mais tradicionais são algumas variáveis explicativas para esse fenômeno (ARBIX, 2000).

Porém, o grande indutor da descentralização produtiva foi a concessão por parte de estados e municípios de vultuosos benefícios para a atração de grandes empreendimentos. Nesse sentido, as benesses incluíam a melhoria e a realização de obras de infra-estrutura, a doação de terrenos, a isenção de taxas e impostos, o diferimento do ICMS, a concessão de crédito subsidiado, entre outras.

Portanto, os rumos seguidos pelo País a partir dos anos 1990 passaram ao largo da preocupação em promover um salto de qualidade na estrutura produtiva brasileira através da necessária monopolização do capital nacional, dotando-o da escala, do porte financeiro e da capacidade de inovação tecnológica requeridas pela competição em escala global. Em verdade, legou-se ao setor privado e, particularmente, à grande empresa multinacional o papel de centro irradiador das transformações econômicas e produtivas, determinando, assim, a forma de inserção da economia brasileira na nova ordem do capital globalizado.

A partir dos anos 2000, com o advento da desvalorização cambial, mudanças importantes ocorreram no padrão de concorrência intercapitalista no Brasil. Um câmbio mais realista concorreu para um aumento das vendas para o exterior das empresas instaladas no país, sobretudo aquelas produtoras de commodities ou de produtos semi-acabados, sem mencionar que os custos em dólar com a mão-de-obra foram sensivelmente reduzidos. Além disso, é bom lembrar que os estímulos para a retomada de um processo de substituição de importações voltaram novamente à cena, tendo como protagonistas as grandes empresas.

Não obstante, as políticas monetária e fiscal, guiadas, respectivamente, pelo regime de metas inflacionárias e pela busca de superávits primários para fazer face ao pagamento dos serviços da dívida, aprofundaram o seu viés ortodoxo a partir do ano 2000, abortando qualquer chance da construção de um crescimento econômico robusto e sustentável ao longo do tempo (BIASOTO JR., 2003; FARHI, 2004).

O saldo das transações comerciais com o exterior, há muito tempo deficitário, voltou a registrar superávits importantes a partir do limiar do novo século, o que foi de suma importância uma vez que tornou o País menos dependente da entrada de capitais externos, possibilitando, em tese, uma queda acentuada da taxa de juros. Ademais, foi justamente o novo impulso exportador registrado de modo mais intenso a partir de 2004 o principal responsável pela retomada do 
crescimento do emprego formal, com destaque especial para o desempenho das grandes empresas (BALTAR, KREIN e MORETTO, 2006).

Partindo deste diagnóstico sobre o descompasso no processo de reestruturação produtiva no Brasil e as suas especificidades, o propósito do presente artigo é discutir em que medida as mudanças da economia brasileira pós-1990 e a redefinição regional da estrutura produtiva impactaram sobre o emprego e os salários, notadamente nas grandes empresas do segmento industrial, e verificar se houve alterações significativas no perfil dos empregados destas empresas.

\section{Objeto de análise, fonte de informação e questões para discussão}

Desenhado o contexto mais geral, podemos, nesse momento, explicar como serão avaliadas empiricamente as inflexões recentes do emprego na grande empresa do setor industrial, no Brasil, frente às mudanças expostas anteriormente.

Nesse sentido, dividiremos nossa análise em três dimensões: i) o comportamento do emprego formal na indústria de transformação; ii) tamanho e localização dos grandes estabelecimentos industriais; e iii) mudanças na estrutura e no perfil do emprego formal nos grandes estabelecimentos industriais.

Para atingir o nosso objetivo, utilizaremos a Relação Anual de Informações Sociais (RAIS) do Ministério do Trabalho e Emprego (MTE), cujas informações se referem sempre ao estoque de emprego em 31 de dezembro do ano referido ${ }^{2}$.

Para efeitos deste estudo, seguindo a classificação adotada pela Pesquisa Industrial Anual (PIA) do IBGE, optamos por selecionar os estabelecimentos da indústria de transformação com mais de 500 empregados como uma proxy da grande empresa industrial instalada no país. Adicionalmente, ainda de acordo com a PIA, consideramos como de porte médio os estabelecimentos com no mínimo 100 empregados e no máximo 499 e como pequeno estabelecimento aquele que possui entre 5 e 99 empregados.

Assim sendo, analisamos o nível de emprego, a remuneração média e o perfil dos empregados nesses estabelecimentos em quatro momentos (1989, 1995, 1999 e 2005) com o intuito de responder às seguintes questões:

- Como evoluiu o emprego formal na indústria e, em particular, nos grandes estabelecimentos a partir das reformas neoliberais iniciadas nos anos $1990 ?$

\footnotetext{
${ }^{2}$ A RAIS é um Registro Administrativo que foi instituído através do decreto $\mathrm{n}^{\mathrm{o}} 76.900$, de 2 de dezembro de 1975 com fins eminentemente fiscalizatórios sobre o mercado de trabalho nacional. Dada a sua riqueza de informações sobre a atividade trabalhista no país, a RAIS logo passou a ser utilizada como uma ferramenta valiosa de informações sobre o segmento do mercado de trabalho brasileiro que apresenta vínculo de emprego formalizado. Atualmente, a RAIS tem periodicidade anual, é declarada por estabelecimento e possui uma cobertura de cerca de $97,0 \%$ do mercado de trabalho formal do país, permitindo, ainda, uma desagregação geográfica dos dados, inclusive, em nível municipal.
} 
- A reestruturação produtiva, intensificada na última década do século passado, impactou de que maneira no tamanho das grandes empresas industriais?

- O novo padrão de concorrência capitalista advindo com a abertura dos mercados impactou de que modo na distribuição dos grandes estabelecimentos industriais pelo território nacional? Quais as regiões do País que se deram melhor na "guerra fiscal”?

- Até que ponto os novos padrões de contratação e de remuneração do trabalhador da grande empresa industrial representam uma ruptura em relação ao passado? Em termos mais específicos:

- Houve uma melhoria significativa no padrão de remuneração da mão-de-obra?

- Os diferenciais de remuneração entre os homens e as mulheres tornaram-se menos acentuados ao longo do período analisado?

- A elevada rotatividade dos postos de trabalho sofreu alguma mudança perceptível?

- O grau de instrução dos trabalhadores foi ampliado? Em que medida a remuneração acompanhou o movimento da escolaridade?

- As mulheres vêm aumentando a participação nos postos de trabalho das grandes empresas na indústria de transformação? Os cargos de direção e gerência têm sido ocupados de modo menos desigual em termos de gênero?

- A disseminação do modelo japonês de administração da produção e do trabalho, juntamente com a flexibilização do marco regulatório das relações trabalhistas, vieram acompanhadas do aumento dos contratos de trabalho flexíveis nas grandes empresas industriais?

Embora seja difícil estabelecer conclusões definitivas a partir do conjunto de informações disponibilizadas pela RAIS, acreditamos que é importante tentar verificar se o processo de introdução das práticas japonesas de administração da produção e do trabalho, iniciado embrionariamente nos anos 1980 e levado adiante até os dias de hoje, significou ou não uma mudança significativa no padrão de contratação e remuneração dos trabalhadores na grande empresa industrial no Brasil. Nossa hipótese é que as pressões impostas por uma concorrência capitalista cada vez mais exacerbada têm deteriorado, para a maior parte dos trabalhadores, as condições de trabalho e remuneração, ao contrário, portanto, do que vislumbravam os defensores da modernização empresarial no início da década passada.

\section{O comportamento do emprego formal na indústria de transformação}

A emergência de um novo regime de acumulação de capital trouxe consigo profundas transformações sobre a estrutura e o funcionamento das economias capitalistas. No que se refere ao 
segmento industrial, em particular, o que se verificou em diferentes partes do mundo foi sua perda de participação relativa frente aos outros setores de atividade econômica, notadamente para os serviços e o comércio. Apontam ainda as diversas experiências nacionais que tal tendência seria particularmente incisiva para a grande empresa industrial uma vez que esta é o espaço por excelência da reestruturação produtiva contemporânea.

Nesse sentido, de acordo com o Gráfico 01, percebemos que entre 1989 e 1999 a indústria no Brasil sofreu uma perda não desprezível de participação no emprego formal, de aproximadamente sete pontos percentuais. Os dois principais setores em termos de absorção de mão-de-obra, os serviços e o comércio, por exemplo, avançaram consideravelmente durante esse mesmo período. Na primeira metade da década atual, o peso do emprego industrial parece ter se estabilizado em torno de 20,0\%, ao passo que o emprego no comércio continuou em expansão, alcançando 18,1\%. O emprego nos serviços registrou uma pequena redução relativa, passando para $54,3 \%$ em 2005.

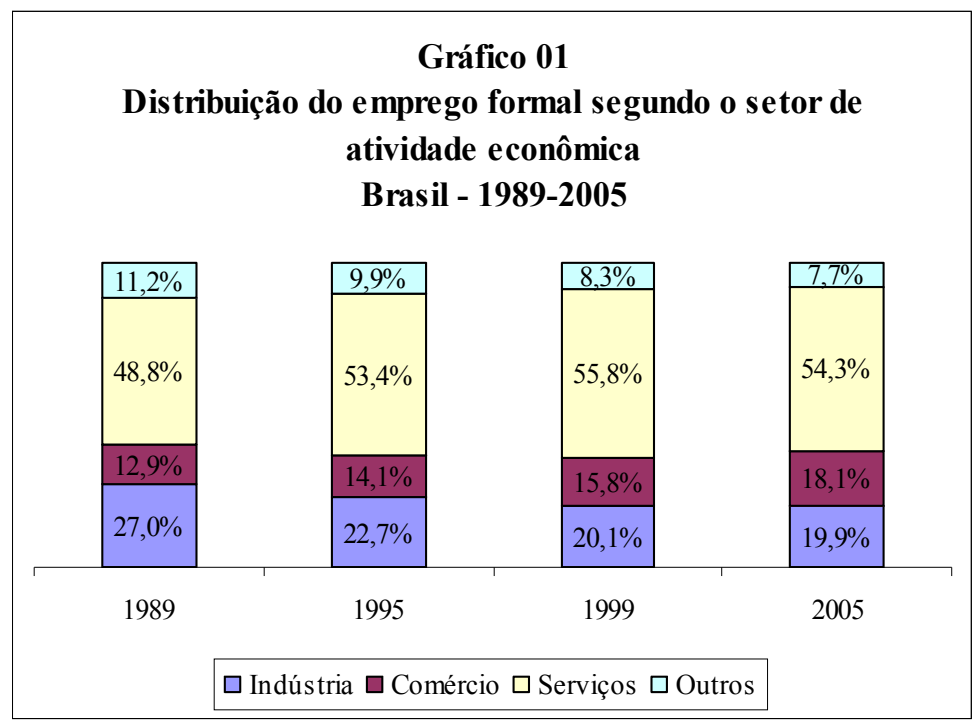

Fonte: RAIS/MTE. Elaboração Própria.

Analisando especificamente o emprego na indústria de transformação, observamos dois comportamentos distintos após a liberalização econômica iniciada nos anos 1990. Num primeiro momento, a abertura dos mercados (acompanhada de um câmbio sobrevalorizado a partir de meados de 1994) impactou diretamente e de modo severo os estabelecimentos de médio e grande porte (redução do emprego formal de $25,2 \%$ e $55,2 \%$, respectivamente). Os pequenos estabelecimentos, por sua vez, registraram um movimento contrário e expandiram os postos de trabalho formais em 13,8\%, muito provavelmente em decorrência da terceirização levada a cabo pelas grandes empresas (Tabela 03). Grande parte desses novos postos de trabalho foi criado em estabelecimentos prestadores de serviços, como segurança, alimentação, limpeza, entre outros. De 
qualquer modo, o aumento do emprego nos pequenos estabelecimentos não compensou o intenso enxugamento do emprego nas grandes empresas industriais.

Uma nova fase foi iniciada após a desvalorização do câmbio em 1999, com recuperação significativa do emprego industrial (o estoque total registrado pela RAIS se aproximou daquele de 1989). A partir desse momento, os grandes estabelecimentos, estimulados pelo boom sofrido pelas exportações, passaram a liderar o crescimento do emprego formal na indústria (crescimento de $55,5 \%$ entre 1999 e 2005), mas o mesmo movimento, ainda que de modo menos intenso, se verificou nos estabelecimentos médios e pequenos (aumento de aproximadamente $21,0 \%$ e 31,0\%, respectivamente). Olhando os dados a partir do final de 2003, conforme nos mostra a Tabela 01, constatamos que em 2004 os grandes estabelecimentos ampliaram os postos de trabalho formais de modo muito mais rápido do que o pequeno e o médio, sendo que a mesma tendência foi verificada em 2005, muito embora o ritmo tenha sido bem mais lento.

\section{Tabela 01}

Evolução do emprego formal na indústria de transformação por tamanho do estabelecimento

Brasil - 1989-2005

\begin{tabular}{|l|c|c|c|c|c|c|c|c|}
\hline $\begin{array}{l}\text { Tamanho do } \\
\text { estabelecimento }\end{array}$ & $\mathbf{1 9 8 9}(\mathbf{a})$ & $\mathbf{1 9 9 9}(\mathbf{b})$ & $\mathbf{b} / \mathbf{a}$ & $\mathbf{2 0 0 3}(\mathbf{c})$ & $\mathbf{2 0 0 4}(\mathbf{d})$ & $\mathbf{d} / \mathbf{c}$ & $\mathbf{2 0 0 5}(\mathbf{e})$ & e/d \\
\hline Pequeno & 1.665 .658 & 1.896 .183 & $13,8 \%$ & 2.219 .807 & 2.393 .126 & $7,8 \%$ & 2.484 .032 & $3,8 \%$ \\
\hline Médio & 1.832 .326 & 1.371 .348 & $-25,2 \%$ & 1.499 .109 & 1.633 .640 & $9,0 \%$ & 1.658 .974 & $1,6 \%$ \\
\hline Grande & 2.497 .322 & 1.119 .297 & $-55,2 \%$ & 1.402 .328 & 1.660 .515 & $18,4 \%$ & 1.740 .516 & $4,8 \%$ \\
\hline Total & 5.995 .306 & 4.386 .828 & $-26,8 \%$ & 5.121 .244 & 5.687 .281 & $11,1 \%$ & 5.883 .522 & $3,5 \%$ \\
\hline
\end{tabular}

Fonte: RAIS/MTE. Elaboração Própria.

Uma análise mais detalhada dos grandes estabelecimentos da indústria de transformação indica que, ao longo dos anos 1990, a tendência geral de encolhimento do emprego industrial se manifestou em todos os seus subsetores, sem exceção. Por outro lado, a partir de 1999, o movimento foi o inverso: a expansão do emprego formal na indústria se apresentou também de modo generalizado, especialmente em 2004 (Tabela 02).

Em 2005, por sua vez, além do crescimento ter sido sensivelmente menor para todos os grandes estabelecimentos industriais, independentemente do subsetor analisado, a indústria da madeira e do mobiliário, a indústria da borracha, fumo, couros, peles e similares e a indústria de calçados contabilizaram uma redução do emprego formal de 7,5\%,6,2\% e 4,9\%, respectivamente. Tal manifestação já é resultado da sobrevalorização cambial iniciada em 2004 e nos fornece um importante indício de como o emprego na indústria pode vir a se comportar caso o câmbio permaneça desajustado por mais algum tempo. 
Tabela 02

Evolução do emprego formal nos estabelecimentos industriais de grande porte segundo o subsetor de atividade econômica Brasil - 1989-2005

\begin{tabular}{|c|c|c|c|c|c|c|c|c|}
\hline Subsetor de atividade econômica & 1989 (a) & 1999 (b) & $\mathbf{b} / \mathbf{a}$ & 2003 (c) & $2004(d)$ & $\mathbf{d} / \mathbf{c}$ & 2005 (e) & d/e \\
\hline Indústria de produtos minerais nao metálicos & 109.578 & 20.898 & $-80,9 \%$ & 23.844 & 25.622 & $7,5 \%$ & 26.014 & $1,5 \%$ \\
\hline Indústria metalúrgica & 287.491 & 130.005 & $-54,8 \%$ & 117.808 & 132.427 & $12,4 \%$ & 138.659 & $4,7 \%$ \\
\hline Indústria mecânica & 153.121 & 63.812 & $-58,3 \%$ & 82.443 & 99.369 & $20,5 \%$ & 101.138 & $1,8 \%$ \\
\hline Indústria do material elétrico e de comunicaçoes & 184.632 & 55.806 & $-69,8 \%$ & 60.602 & 71.780 & $18,4 \%$ & 82.998 & $15,6 \%$ \\
\hline Indústria do material de transporte & 321.087 & 158.353 & $-50,7 \%$ & 190.497 & 235.207 & $23,5 \%$ & 253.325 & $7,7 \%$ \\
\hline Indústria da madeira e do mobiliário & 50.807 & 22.439 & $-55,8 \%$ & 31.183 & 41.516 & $33,1 \%$ & 38.388 & $-7,5 \%$ \\
\hline Indústria do papel, papelao, editorial e gráfica & 112.633 & 53.199 & $-52,8 \%$ & 50.118 & 54.795 & $9,3 \%$ & 55.843 & $1,9 \%$ \\
\hline $\begin{array}{l}\text { Ind. da borracha, fumo, couros, peles, similares, } \\
\text { ind. diversas }\end{array}$ & 133.430 & 36.415 & $-72,7 \%$ & 45.664 & 54.434 & $19,2 \%$ & 51.035 & $-6,2 \%$ \\
\hline $\begin{array}{l}\text { Ind. química de produtos farmacêuticos, } \\
\text { veterinários, perfumaria, ... }\end{array}$ & 199.736 & 66.162 & $-66,9 \%$ & 83.469 & 95.811 & $14,8 \%$ & 101.195 & $5,6 \%$ \\
\hline $\begin{array}{l}\text { Indústria têxtil do vestuário e artefatos de } \\
\text { tecidos }\end{array}$ & 359.322 & 122.421 & $-65,9 \%$ & 121.556 & 131.269 & $8,0 \%$ & 135.145 & $3,0 \%$ \\
\hline Indústria de calçados & 108.621 & 80.708 & $-25,7 \%$ & 107.846 & 125.589 & $16,5 \%$ & 119.460 & $-4,9 \%$ \\
\hline $\begin{array}{l}\text { Indústria de produtos alimentícios, bebidas e } \\
\text { álcool etílico }\end{array}$ & 476.864 & 309.079 & $-35,2 \%$ & 487.298 & 592.696 & $21,6 \%$ & 637.316 & $7,5 \%$ \\
\hline Total & 2.497 .322 & 1.119 .297 & $-55,2 \%$ & 1.402 .328 & 1.660 .515 & $18,4 \%$ & 1.740 .516 & $4,8 \%$ \\
\hline
\end{tabular}

Fonte: RAIS/MTE. Elaboração Própria.

Analisando a distribuição da mão-de-obra empregada na indústria de transformação segundo o tamanho do estabelecimento, percebemos que no decorrer dos anos 1990 o grande estabelecimento perdeu participação da ordem de 16 pontos percentuais: saindo de 41,7\% em 1989 e atingindo $25,5 \%$ em 1999. Somente a partir dos anos 2000 é que houve um movimento de ampliação do peso dos postos de trabalho vinculados a esses estabelecimentos, conforme demonstra o Gráfico 02.

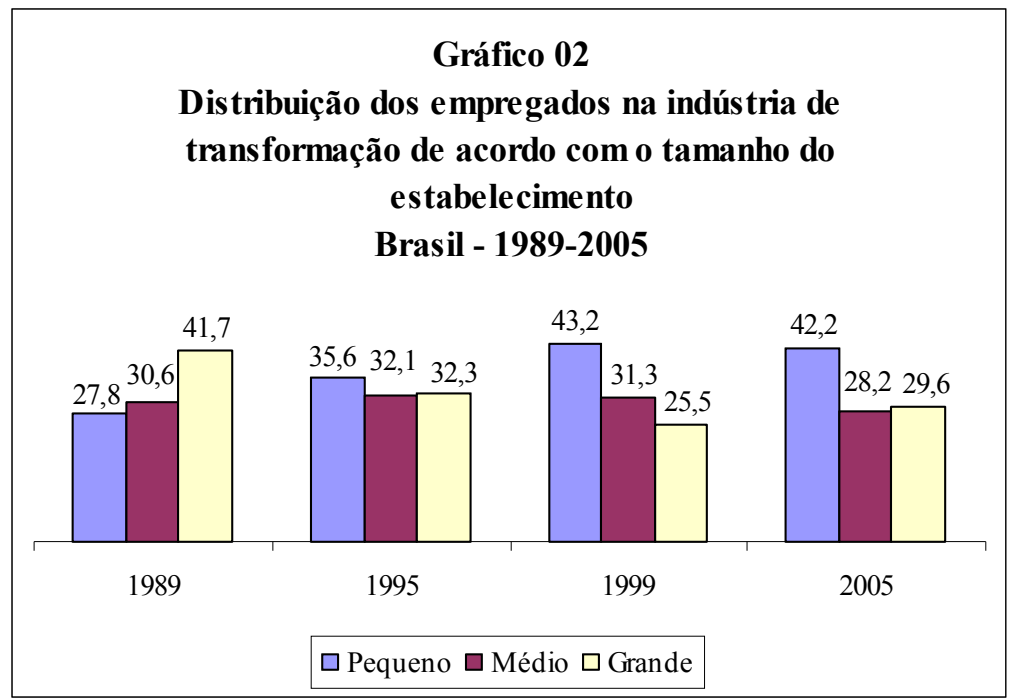

Fonte: RAIS/MTE. Elaboração Própria.

Em suma, percebemos que a partir dos anos 1990 a geração do emprego formal deslocou-se da indústria para os setores de serviços e do comércio. Nesse processo, a grande empresa industrial 
foi perdendo participação de maneira expressiva em relação às firmas de pequeno e médio porte. Tudo indicava uma tendência inexorável e irreversível neste sentido. Contudo, um olhar sobre os primeiros anos do século XXI sugere uma nova dinâmica para o emprego na grande empresa industrial, enquanto a indústria foi capaz de manter a sua participação, em termos relativos, no núcleo mais estruturado do mercado de trabalho.

A retomada do crescimento do emprego formal na indústria, intimamente ligada ao comportamento da grande empresa, indica, de um lado, que a reestruturação produtiva poupadora de mão-de-obra vem perdendo fôlego nos anos mais recentes na maioria dos ramos industriais e, de outro, que o crescimento significativo das exportações, notadamente a partir de 2004, funcionou como uma mola propulsora na criação de novos empregos industriais nessas empresas. Além disso, ficou evidente que uma retomada na taxa de crescimento do PIB (e da demanda agregada) tem uma influência direta sobre a geração de empregos industriais, mesmo no caso de ramos em que predomina a incorporação de inovações tecnológicas e a busca recorrente por ganhos de produtividade.

\section{Tamanho e localização dos grandes estabelecimentos industriais}

Uma dimensão importante da nossa análise empírica corresponde à variação no tamanho médio e na localização regional dos estabelecimentos de grande porte na indústria de transformação a partir dos anos 1990. Como já apontamos, a grande empresa "pós-fordista" passou, auxiliada pelo avanço da tecnologia microeletrônica, por um forte processo de desverticalização (o que implicou no redimensionamento do tamanho das plantas) e de relocalização espacial, organizando-se no formato de redes, em resposta aos desafios colocados pela emergência de um novo regime de acumulação do capital.

A tendência apontada pela literatura internacional e brasileira era a de que as grandes firmas, além de estarem reduzindo o tamanho das plantas e o número de funcionários diretos, estariam se transferindo para as regiões que oferecessem condições mais vantajosas em termos de custos de produção e da mão-de-obra impelidas pela nova ordem competitiva do capital.

Assim sendo, analisando a Tabela 03, percebemos que na década de 1990 houve uma redução substancial dos estabelecimentos considerados de grande porte na indústria de transformação brasileira, bem como da mão-de-obra empregada por eles. Para ilustrar, os grandes estabelecimentos eram, em 1989, cerca de 2.100 ao passo que, em 1999, foram reduzidos praticamente a metade. Os trabalhadores dos grandes estabelecimentos, por sua vez, estavam em torno de 1,1 milhão no ano de 1999 enquanto em 1989 eram quase 2,5 milhões. Portanto, além de 
forte redução no número de estabelecimentos de grande porte, o número médio de empregados por estabelecimento também se reduziu (como será mostrado a seguir).

No entanto, a partir dos anos 2000 houve uma inflexão da trajetória apresentada com a retomada do crescimento dos grandes estabelecimentos na indústria de transformação (passando para cerca de 1.450 em 2005) e dos postos de trabalho gerados nesse segmento (atingindo quase 1,8 milhão de empregos em 2005). Embora ainda não se tenha alcançado o patamar verificado em 1989, a inflexão fica bem evidente na Tabela 03.

\section{Tabela 03}

Evolução da quantidade de grandes estabelecimentos e da

mão-de-obra empregada

Brasil - 1989-2005

\begin{tabular}{|r|r|r|r|r|}
\hline Ano & Estabelecimentos & Variação & Empregados & Variação \\
\hline 1989 & 2.066 & - & 2.497 .322 & - \\
\hline 1995 & 1.330 & $-35,6 \%$ & 1.523 .276 & $-39,0 \%$ \\
\hline 1999 & 1.011 & $-24,0 \%$ & 1.119 .297 & $-26,5 \%$ \\
\hline 2005 & 1.449 & $43,3 \%$ & 1.740 .516 & $55,5 \%$ \\
\hline
\end{tabular}

Fonte: RAIS/MTE. Elaboração Própria.

O Gráfico 03 demonstra que na década de 1990 houve, no Brasil, uma redução do tamanho médio dos grandes estabelecimentos industriais sob a ótica do número de empregados: em 1989, era de 1.209 , ao passo que, em 1999, era de 1.107. Com a retomada do crescimento do emprego formal puxado pela grande empresa, a partir dos anos 2000 o tamanho médio dos grandes estabelecimentos industriais voltou a crescer, atingindo o patamar de 1.201.

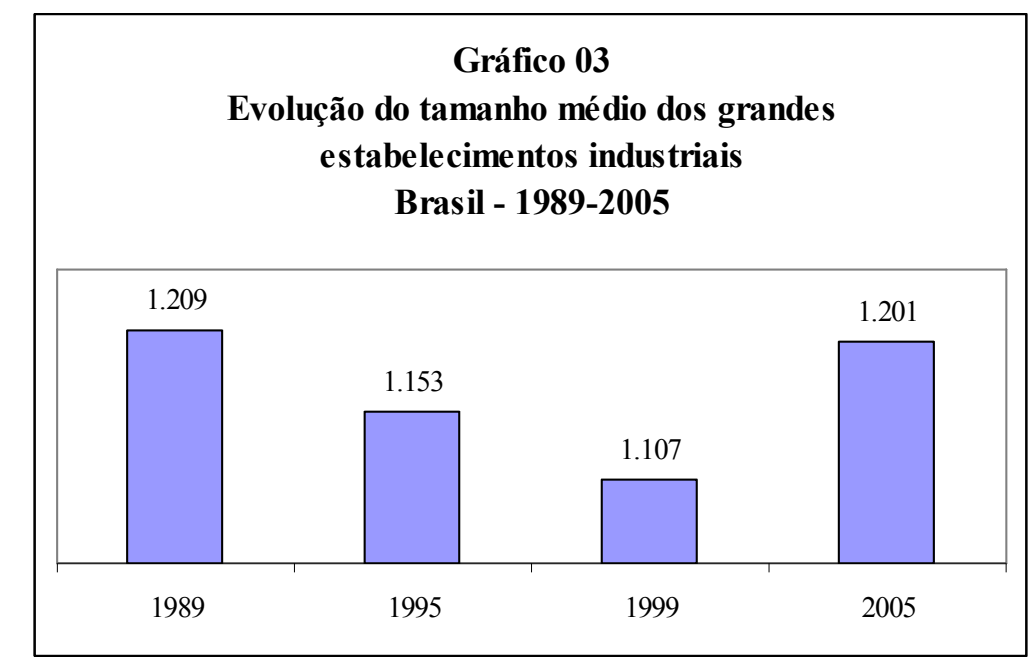

Fonte: RAIS/MTE. Elaboração Própria.

No que se refere especificamente à localização dos grandes estabelecimentos industriais, observa-se que, entre 1989 e 2005, há uma clara tendência de perda de participação da região sudeste, muito embora nela ainda se concentre mais da metade desses estabelecimentos. Em 1989, 
por exemplo, cerca de $64,0 \%$ dos estabelecimentos industriais considerados de grande porte estavam localizados no sudeste do país; já em 2005, esse percentual se encontrava ao redor de $51,0 \%$, uma queda de aproximadamente 13,0 pontos percentuais.

Em contraposição, todas as demais regiões aumentaram ou mantiveram as suas participações relativas no total dos grandes estabelecimentos na indústria. O destaque ficou por conta da região sul, que ao crescer ininterruptamente nesse período consolidou-se como a segunda região brasileira com maior número de estabelecimentos de grande porte no segmento industrial (27,2\%).

O nordeste, em particular, após ter registrado um crescimento relativo, ainda que lento, ao longo da década de 1990, contabilizou nos anos 2000 um recuo, aproximando-se dos níveis encontrados no final da década de 1980 (Tabela 04).

Tabela 04

Localização dos grandes estabelecimentos industriais segundo a região natural

Brasil - 1989-2005

\begin{tabular}{|l|r|r|r|r|r|r|r|r|}
\hline Região Natural & $\mathbf{1 9 8 9}$ & $\mathbf{\%}$ & $\mathbf{1 9 9 5}$ & $\mathbf{\%}$ & $\mathbf{1 9 9 9}$ & $\mathbf{\%}$ & $\mathbf{2 0 0 5}$ & $\mathbf{\%}$ \\
\hline Norte & 70 & 3,4 & 33 & 2,5 & 23 & 2,3 & 71 & 4,9 \\
\hline Nordeste & 252 & 12,2 & 172 & 12,9 & 136 & 13,5 & 175 & 12,1 \\
\hline Sudeste & 1.314 & 63,6 & 796 & 59,8 & 563 & 55,7 & 742 & 51,2 \\
\hline Sul & 410 & 19,8 & 300 & 22,6 & 264 & 26,1 & 394 & 27,2 \\
\hline Centro-Oeste & 20 & 1,0 & 29 & 2,2 & 25 & 2,5 & 67 & 4,6 \\
\hline Brasil & 2.066 & 100,0 & 1.330 & 100,0 & 1.011 & 100,0 & 1.449 & 100,0 \\
\hline
\end{tabular}

Fonte: RAIS/MTE. Elaboração Própria.

Vista a localização dos grandes estabelecimentos industriais pela ótica dos espaços metropolitanos $^{3}$, percebe-se que, no Brasil, houve um movimento geral de interiorização dos grandes investimentos produtivos. As regiões não-metropolitanas, por exemplo, em 2005, reuniam algo em torno de $67,0 \%$ dos estabelecimentos de grande porte do setor industrial enquanto, em 1989, esse patamar era um pouco inferior a 50,0\%. Dito de outra forma, houve uma desconcentração industrial: as principais regiões metropolitanas brasileiras tiveram uma redução na participação relativa no número de estabelecimentos industriais de grande porte (de 50,3\%, em 1989, para 32,9\% em 2005).

No comparativo 1989-2005, em todas as grandes regiões brasileiras se verificou uma desconcentração dos investimentos em prol das regiões não-metropolitanas. O norte, nesse quesito, é a região onde as metrópoles detêm a menor participação em termos de localização dos grandes

\footnotetext{
${ }^{3}$ As regiões metropolitanas consideradas nesse artigo foram Belém, Fortaleza, Recife, Salvador, Belo Horizonte, Rio de Janeiro, São Paulo, Curitiba e Porto Alegre, conforme a classificação sugerida pelo Ministério do Trabalho e Emprego (MTE).
} 
estabelecimentos industriais, apenas $11,3 \%^{4}$, ao passo que é no sudeste que as regiões metropolitanas possuem uma importância mais acentuada (40,2\%) (Tabela 05).

Tabela 05

Localização dos grandes estabelecimentos industriais segundo a região natural*

Brasil - 1989-2005

\begin{tabular}{|l|l|r|r|r|r|r|r|r|r|}
\hline Localização & $\mathbf{1 9 8 9}$ & $\mathbf{\%}$ & $\mathbf{1 9 9 5}$ & $\mathbf{\%}$ & $\mathbf{1 9 9 9}$ & $\mathbf{\%}$ & $\mathbf{2 0 0 5}$ & $\mathbf{\%}$ \\
\hline \multirow{2}{*}{ Norte } & Regiões metropolitanas & 15 & 21,4 & 7 & 21,2 & 3 & 13,0 & 8 & 11,3 \\
\cline { 2 - 10 } & Regiões não-metropolitanas & 55 & 78,6 & 26 & 78,8 & 20 & 87,0 & 63 & 88,7 \\
\hline \multirow{2}{*}{ Nordeste } & Regiões metropolitanas & 116 & 46,0 & 71 & 41,3 & 57 & 41,9 & 60 & 34,3 \\
\cline { 2 - 10 } & Regiões não-metropolitanas & 136 & 54,0 & 101 & 58,7 & 79 & 58,1 & 115 & 65,7 \\
\hline \multirow{2}{*}{ Sudeste } & Regiões metropolitanas & 753 & 57,3 & 422 & 53,0 & 249 & 44,2 & 298 & 40,2 \\
\cline { 2 - 9 } & Regiões não-metropolitanas & 561 & 42,7 & 374 & 47,0 & 314 & 55,8 & 444 & 59,8 \\
\hline \multirow{2}{*}{ Sul } & Regiões metropolitanas & 154 & 37,6 & 103 & 34,3 & 75 & 28,4 & 111 & 28,2 \\
\cline { 2 - 9 } & Regiões não-metropolitanas & 256 & 62,4 & 197 & 65,7 & 189 & 71,6 & 283 & 71,8 \\
\hline \multirow{2}{*}{ Brasil } & Regiões metropolitanas & 1.038 & 50,3 & 603 & 45,3 & 384 & 38,0 & 477 & 32,9 \\
\cline { 2 - 9 } & Regiões não-metropolitanas & 1.024 & 49,7 & 727 & 54,7 & 627 & 62,0 & 972 & 67,1 \\
\hline
\end{tabular}

Fonte: RAIS/MTE. Elaboração Própria.

* Excluido os ignorados.

Seguindo a tendência apontada acima, o sudeste também perdeu participação no total da mão-de-obra empregada nos grandes estabelecimentos industriais entre 1989 e 2005, caindo de $64,5 \%$ para o patamar de 49,0\% nesse último ano. Por outro lado, as demais regiões assinalaram um crescimento nesse período, com destaque para o sul (que atingiu 25,2\% em 2005) e para o nordeste (com participação de aproximadamente 18,0\% em 2005) (Tabela 06).

\section{Tabela 06}

Distribuição dos empregados nos grandes estabelecimentos industriais segundo a região natural

Brasil - 1989-2005

\begin{tabular}{|c|c|c|c|c|c|c|c|c|}
\hline Região Natural & 1989 & $\%$ & 1995 & $\%$ & 1999 & $\%$ & 2005 & $\%$ \\
\hline Norte & 70.645 & 2,8 & 33.954 & 2,2 & 20.422 & 1,8 & 69.651 & 4,0 \\
\hline Nordeste & 355.430 & 14,2 & 239.355 & 15,7 & 186.894 & 16,7 & 306.824 & 17,6 \\
\hline Sudeste & 1.611 .314 & 64,5 & 907.581 & 59,6 & 623.708 & 55,7 & 849.503 & 48,8 \\
\hline Sul & 437.189 & 17,5 & 316.378 & 20,8 & 264.978 & 23,7 & 439.109 & 25,2 \\
\hline Centro-Oeste & 22.744 & 0,9 & 26.008 & 1,7 & 23.295 & 2,1 & 75.429 & 4,3 \\
\hline Brasil & 2.497 .322 & 100,0 & 1.523 .276 & 100,0 & 1.119 .297 & 100,0 & 1.740 .516 & 100,0 \\
\hline
\end{tabular}

Fonte:RAIS/MTE. Elaboração Própria.

Um dos efeitos da interiorização do aparelho produtivo no Brasil é a perda de importância das regiões metropolitanas no emprego formal ligado aos grandes estabelecimentos. Como podemos

\footnotetext{
${ }^{4}$ É importante salientarmos que a baixa participação das regiões metropolitanas no emprego formal da indústria de transformação na região norte, deve-se ao fato da classificação adotada não considerar Manaus um espaço metropolitano. Em 1989, por exemplo, a capital do Amazonas reunia cerca de 60,0\% dos grandes estabelecimentos da indústria de transformação localizados na região norte do país. Em 2005, por sua vez, esse percentual girava em torno de $68,0 \%$.
} 
observar na tabela abaixo, todos os estados listados registraram uma menor participação do emprego metropolitano vis-à-vis ao não-metropolitano entre 1989 e 2005 . Os destaques ficam por conta dos estados da Bahia, do Ceará e do Pará que contabilizaram, respectivamente, uma redução de $46,9,31,7$ e 26,8 pontos percentuais no emprego industrial metropolitano nos grandes estabelecimentos nesse mesmo intervalo de tempo (Tabela 07).

Tabela 07

Distribuição dos empregados nos grandes estabelecimentos industriais segundo regiões metropolitanas em estados selecionados

Brasil - 1989-2005

\begin{tabular}{|l|r|r|r|r|}
\hline Estado/Região Metropolitana & \multicolumn{1}{|c|}{$\mathbf{1 9 8 9}$} & \multicolumn{1}{|c|}{$\mathbf{1 9 9 5}$} & \multicolumn{1}{|c|}{$\mathbf{1 9 9 9}$} & \multicolumn{1}{|c|}{$\mathbf{2 0 0 5}$} \\
\hline Pará (a) & 17.441 & 11.308 & 6.308 & 16.097 \\
\hline Região Metropolitana (b) & 10.597 & 4.593 & 2.585 & 5.471 \\
\hline b/a & $60,8 \%$ & $40,6 \%$ & $41,0 \%$ & $34,0 \%$ \\
\hline Ceará (a) & 48.813 & 43.081 & 53.604 & 73.416 \\
\hline Região Metropolitana (b) & 44.692 & 35.542 & 34.409 & 43.956 \\
\hline b/a & $91,6 \%$ & $82,5 \%$ & $64,2 \%$ & $59,9 \%$ \\
\hline Pernambuco (a) & 147.534 & 83.717 & 47.975 & 65.215 \\
\hline Região Metropolitana (b) & 69.030 & 31.624 & 23.264 & 25.794 \\
\hline b/a & $46,8 \%$ & $37,8 \%$ & $48,5 \%$ & $39,6 \%$ \\
\hline Bahia (a) & 39.601 & 19.470 & 13.446 & 41.065 \\
\hline Região Metropolitana (b) & 28.726 & 9.004 & 5.195 & 10.508 \\
\hline b/a & $72,5 \%$ & $46,2 \%$ & $38,6 \%$ & $25,6 \%$ \\
\hline Minas Gerais (a) & 181.076 & 133.879 & 104.968 & 150.803 \\
\hline Região Metropolitana (b) & 65.364 & 54.764 & 33.791 & 41.400 \\
\hline b/a & $36,1 \%$ & $40,9 \%$ & $32,2 \%$ & $27,5 \%$ \\
\hline Rio de Janeiro (a) & 244.854 & 111.164 & 64.695 & 89.407 \\
\hline Região Metropolitana (b) & 169.180 & 73.388 & 43.251 & 58.612 \\
\hline b/a & $69,1 \%$ & $66,0 \%$ & $66,9 \%$ & $65,6 \%$ \\
\hline São Paulo (a) & 1.163 .638 & 647.420 & 440.996 & 595.638 \\
\hline Região Metropolitana (b) & 668.003 & 341.594 & 205.199 & 236.443 \\
\hline b/a & $57,4 \%$ & $52,8 \%$ & $46,5 \%$ & $39,7 \%$ \\
\hline Paraná (a) & 82.360 & 68.748 & 56.348 & 132.519 \\
\hline Região Metropolitana (b) & 42.040 & 25.169 & 22.528 & 44.846 \\
\hline b/a & $51,0 \%$ & $36,6 \%$ & $40,0 \%$ & $33,8 \%$ \\
\hline Rio Grande do Sul (a) & 202.539 & 131.091 & 108.529 & 161.141 \\
\hline Região Metropolitana (b) & 110.190 & 69.514 & 44.075 & 69.047 \\
\hline b/a & $54,4 \%$ & $53,0 \%$ & $40,6 \%$ & $42,8 \%$ \\
\hline Fonte:RAIS/MTE. Elaboração Própria. & & & & \\
\hline
\end{tabular}

Do exposto acima, podemos concluir que os dados foram bastante evidentes no sentido de referendar o que diz a literatura sobre as transformações sofridas pela grande empresa e pelo mundo do trabalho a partir dos anos 1990 e, consequentemente, a hipótese sugerida na introdução deste estudo. Realmente, os processos de terceirização e de enxugamento das empresas, princípios importantes do ideário japonês, foram incisivos nos anos 1990 a ponto de ter sido registrada uma redução da importância dos grandes estabelecimentos na indústria de transformação na geração de postos de trabalho com carteira assinada. Ademais, não podemos menosprezar os efeitos importantes do baixo crescimento econômico que, por certo, tiveram uma influência significativa sobre a evolução recente do emprego na indústria de transformação. 
Além disso, as novas estratégias de concorrência adotadas pelas grandes empresas, compelidas pela globalização neoliberal do capital, privilegiaram, a partir dos anos 1990, regiões brasileiras menos tradicionais do ponto de vista da produção industrial, o que acarretou uma perda relativa no peso do sudeste, e o avanço do grande capital em direção a municípios localizados fora das principais regiões metropolitanas do país.

\section{Mudanças na estrutura e no perfil do emprego nos grandes estabelecimentos industriais}

Um outro aspecto importante que nos ajudará a compreender as transformações pelas quais passou o emprego na grande empresa industrial a partir dos anos 1990, no Brasil, está ligada às mudanças de sua estrutura e de seu perfil ao longo desse período.

Como já destacamos, a prevalência de um regime de acumulação flexível nos países capitalistas está moldando uma classe trabalhadora mais heterogênea expressa pela diversidade nas formas de contratação, de utilização e de remuneração do seu tempo de trabalho. Para as empresas, uma mão-de-obra de fácil contratação e demissão, multifuncional, de maior nível de escolaridade e remunerada, em algum grau, de acordo com o seu desempenho (individual ou de grupos), preencheria todos os requisitos demandados por um capitalismo extremamente competitivo, "desregulado" e altamente volátil.

Nesses termos, o mercado de trabalho tem se tornado, via de regra, mais inseguro, com jornadas de trabalho cada vez mais intensas e extensas, com remunerações incertas e com amplos segmentos em dificuldades crescentes de se apropriar dos ganhos de produtividade, sem falar do seu caráter excludente. Mas, se não existem dúvidas que essa é a realidade para uma grande parcela dos trabalhadores, também é verdade que para alguns o trabalho tornou-se mais qualificado e melhor remunerado.

Muito embora trace um quadro comum para as transformações do mundo do trabalho atual, tais características encontram-se de modo bastante diferenciado nos diversos países. No Brasil, assim como em outras nações subdesenvolvidas, a situação acima descrita se apresenta, em linhas gerais, de modo muito mais acentuado e a modernização convive lado a lado com a manutenção do atraso.

Tendo isso em mente, passemos à análise da estrutura do emprego nos grandes estabelecimentos industriais no Brasil. Um primeiro aspecto a ser destacado é o seu comportamento em termos dos subsetores da atividade econômica. Nesse sentido, percebemos que, em termos relativos, o maior aumento de participação coube ao ramo de produtos alimentícios, bebidas e álcool etílico: saindo de 19,1\% em 1989 e atingindo 36,6\% em 2005, o que perfaz um aumento de 17,5 pontos percentuais e consolida a sua posição de maior empregador da indústria de 
transformação brasileira. Em segundo lugar, bem atrás, aparece a indústria de material de transporte com 14,6\% do emprego industrial em 2005.

$\mathrm{Na}$ outra ponta, temos a indústria metalúrgica (queda de 3,5 pontos percentuais) e a indústria têxtil do vestuário e artefatos de tecidos (queda de 6,6 pontos percentuais) como principais exemplos de subsetores que encolheram relativamente entre 1989 e 2005 (Tabela 08).

\section{Tabela 08}

Distribuição dos empregados nos grandes estabelecimentos industriais segundo o subsetor de atividade econômica Brasil - 1898-2005

\begin{tabular}{|c|c|c|c|c|c|c|c|c|}
\hline Subsetor de atividade econômica & 1989 & $\%$ & 1995 & $\%$ & 1999 & $\%$ & 2005 & $\%$ \\
\hline Indústria de produtos minerais nao metálicos & 109.578 & 4,4 & 36.861 & 2,4 & 20.898 & 1,9 & 26.014 & 1,5 \\
\hline Indústria metalúrgica & 287.491 & 11,5 & 155.939 & 10,2 & 130.005 & 11,6 & 138.659 & 8,0 \\
\hline Indústria mecânica & 153.121 & 6,1 & 90.644 & 6,0 & 63.812 & 5,7 & 101.138 & 5,8 \\
\hline Indústria do material elétrico e de comunicaçoes & 184.632 & 7,4 & 89.482 & 5,9 & 55.806 & 5,0 & 82.998 & 4,8 \\
\hline Indústria do material de transporte & 321.087 & 12,9 & 197.348 & 13,0 & 158.353 & 14,1 & 253.325 & 14,6 \\
\hline Indústria da madeira e do mobiliário & 50.807 & 2,0 & 26.033 & 1,7 & 22.439 & 2,0 & 38.388 & 2,2 \\
\hline Indústria do papel, papelao, editorial e gráfica & 112.633 & 4,5 & 76.247 & 5,0 & 53.199 & 4,8 & 55.843 & 3,2 \\
\hline $\begin{array}{l}\text { Ind. da borracha, fumo, couros, peles, similares, } \\
\text { ind. diversas }\end{array}$ & 133.430 & 5,3 & 54.652 & 3,6 & 36.415 & 3,3 & 51.035 & 2,9 \\
\hline $\begin{array}{l}\text { Ind. química de produtos farmacêuticos, } \\
\text { veterinários, perfumaria, ... }\end{array}$ & 199.736 & 8,0 & 98.655 & 6,5 & 66.162 & 5,9 & 101.195 & 5,8 \\
\hline $\begin{array}{l}\text { Indústria têxtil do vestuário e artefatos de } \\
\text { tecidos }\end{array}$ & 359.322 & 14,4 & 179.758 & 11,8 & 122.421 & 10,9 & 135.145 & 7,8 \\
\hline Indústria de calçados & 108.621 & 4,3 & 74.610 & 4,9 & 80.708 & 7,2 & 119.460 & 6,9 \\
\hline $\begin{array}{l}\text { Indústria de produtos alimentícios, bebidas e } \\
\text { álcool etílico }\end{array}$ & 476.864 & 19,1 & 443.047 & 29,1 & 309.079 & 27,6 & 637.316 & 36,6 \\
\hline Total & 2.497 .322 & 100,0 & 1.523 .276 & 100,0 & 1.119 .297 & 100,0 & 1.740 .516 & 100,0 \\
\hline
\end{tabular}

Fonte:RAIS/MTE. Elaboração Própria.

Em termos de gênero, não houve mudanças significativas na distribuição entre 1989 e 2005. Nesse último ano, por exemplo, o trabalhador masculino respondia por cerca de $75,0 \%$ das vagas nos grandes estabelecimentos industriais, ao passo que as mulheres ocupavam aproximadamente 25,0\%. Assim sendo, muito embora a participação feminina no mercado de trabalho tenha crescido consideravelmente nesse intervalo de tempo, a entrada da mulher no emprego formal vinculado à grande empresa industrial ainda acontece de forma muito tímida (Tabela 09).

Tabela 09

Distribuição dos empregados nos grandes estabelecimentos industriais segundo o gênero

Brasil - 1989-2005

\begin{tabular}{|c|c|c|c|c|c|c|c|c|}
\hline Gênero & 1989 & $\%$ & 1995 & $\%$ & 1999 & $\%$ & 2005 & $\%$ \\
\hline Masculino & 1.897 .718 & 76,0 & 1.191 .313 & 78,2 & 854.485 & 76,3 & 1.310 .954 & 75,3 \\
\hline Feminino & 599.604 & 24,0 & 331.963 & 21,8 & 264.812 & 23,7 & 429.562 & 24,7 \\
\hline Total & 2.497 .322 & 100,0 & 1.523 .276 & 100,0 & 1.119 .297 & 100,0 & 1.740 .516 & 100,0 \\
\hline
\end{tabular}

Fonte:RAIS/MTE. Elaboração Própria. 
Além disso, as mulheres que conseguem se inserir no mercado de trabalho formal por meio da grande empresa industrial dificilmente são aproveitadas nos cargos de direção e gerência, que são ocupados em geral por trabalhadores do sexo masculino (Gráfico 04) ${ }^{5}$.

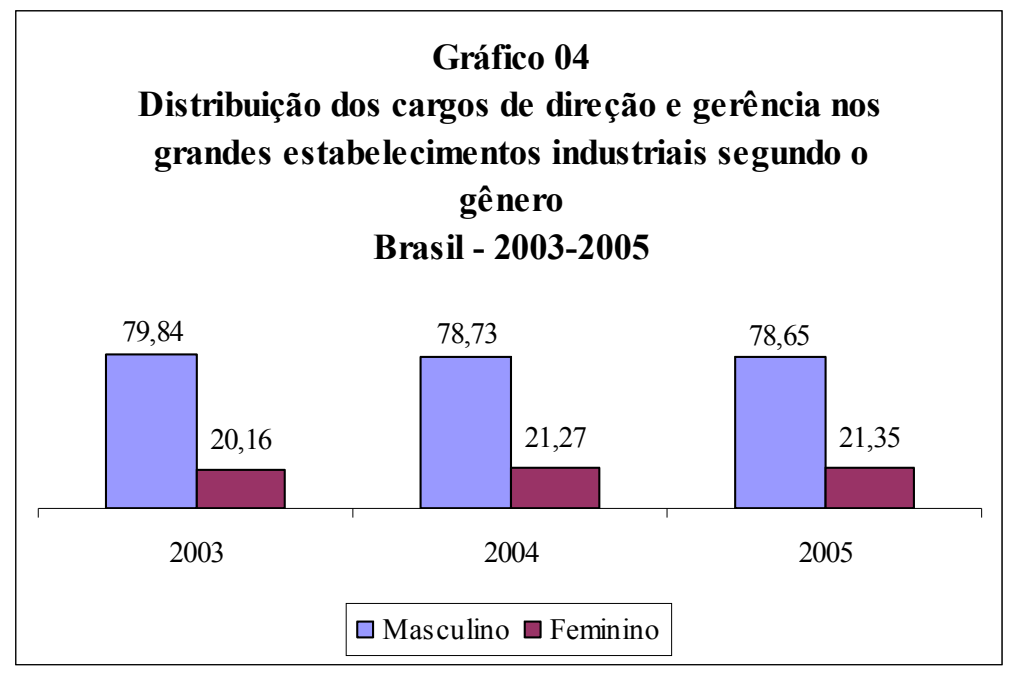

Fonte: RAIS/MTE. Elaboração Própria.

Sob a ótica da faixa etária, observamos que a mudança também foi significativa. Destaque para a perda de participação relativa da população com até 24 anos em relação aos trabalhadores com idade mais avançada, notadamente para aqueles de 30 a 49 anos, ao longo dos anos 1990. Em verdade, tal tendência reflete as dificuldades que os trabalhadores jovens vêm enfrentando para se inserir no mercado de trabalho, em especial no segmento formal melhor estruturado, uma vez que experiência e conhecimento acumulado são bastante valorizados nas grandes empresas. Salientemos, contudo, que a partir dos anos 2000 a população jovem (18 a 24 anos) volta a ampliar a sua participação relativa no mercado de trabalho formal ligado aos estabelecimentos de grande porte da indústria de transformação (Tabela 10).

\footnotetext{
${ }^{5}$ A Classificação Brasileira de Ocupações (CBO) sofreu uma grande reformulação no ano de 2002, o que acarretou uma quebra da série histórica dos dados. Por isso, o Gráfico 05 se restringe aos anos de 2003 a 2005.
} 
Tabela 10

Distribuição dos empregados nos grandes estabelecimentos industriais segundo a faixa etária

Brasil - 1989-2005

\begin{tabular}{|c|c|c|c|c|c|c|c|c|}
\hline ria & 989 & $\%$ & 995 & $\%$ & 1999 & $\%$ & 2005 & $\%$ \\
\hline Ate 17 & & 4,1 & 35.553 & 2,3 & 14.185 & 1,3 & & 0,6 \\
\hline & & 24,8 & 09.8 & 20,3 & & 21,3 & 81 & 23,0 \\
\hline $5 \mathrm{a}$ & & 19,4 & 2 & 19 , & & 19,9 & & \\
\hline $0 \mathrm{a}$ & 765 & 30,6 & 506.399 & 33,2 & & 34,6 & & 30,8 \\
\hline $0 \mathrm{a}$ & 372 & 14,9 & 285.730 & 18,8 & 203 & 18 , & & 18,8 \\
\hline $50 \mathrm{a}$ & 137 & 5,5 & 82.083 & 5,4 & & & 056 & 5,5 \\
\hline $5 \mathrm{ou}$ & & 0,3 & 4.115 & 0,3 & 1.776 & 0 , & 3.244 & 0,2 \\
\hline Ignorado & & 0,2 & & 0,0 & 69 & 0,0 & 5 & 0,0 \\
\hline Total & 2.497 .322 & 100,0 & 1.523 .276 & 100,0 & 1.119 .297 & 100,0 & 1.740 .516 & 100,0 \\
\hline
\end{tabular}

Fonte:RAIS/MTE. Elaboração Própria.

No tocante ao grau de escolaridade da força de trabalho, no período 1989/2005 houve uma clara tendência do aumento dos anos de estudo da mão-de-obra empregada nos grandes estabelecimentos industriais. A participação dos trabalhadores sem instrução ou com ensino fundamental incompleto, por exemplo, reduziu-se de 63,5\% em 1989 para 29,4\% em 2005 enquanto a proporção daqueles com o ensino médio completo ou superior registrou um acréscimo igualmente expressivo: de 16,3\% em 1989 para 46,8\% em 2005 (Tabela 11).

Tal tendência vai ao encontro das mudanças japonesas de gestão da produção e do trabalho que, em tese, ao delegar uma maior autonomia ao trabalhador e disponibilizar máquinas e equipamentos de base microeletrônica necessitam de uma mão-de-obra mais escolarizada e participativa. Porém, é provável que a melhoria no grau de instrução não tenha sido uma exigência da modernização tecnológica e organizacional da indústria, mas conseqüência da melhoria no nível educacional da população em geral e do processo de seleção feito em tempos de redução do quadro de pessoal.

Tabela 11

Distribuição dos empregados nos grandes estabelecimentos industriais segundo o grau de instrução

Brasil - 1989-2005

\begin{tabular}{|c|c|c|c|c|c|c|c|c|}
\hline Grau de instrução & 1989 & $\%$ & 1995 & $\%$ & 1999 & $\%$ & 2005 & $\%$ \\
\hline Analfabeto & 102.398 & 4,1 & 75.900 & 5,0 & 39.757 & 3,6 & 38.302 & 2,2 \\
\hline $\begin{array}{l}\text { Ensino fundamental } \\
\text { incompleto }\end{array}$ & 1.483 .815 & 59,4 & 763.434 & 50,1 & 412.343 & 36,8 & 473.989 & 27,2 \\
\hline $\begin{array}{l}\text { Ensino fundamental } \\
\text { completo }\end{array}$ & 309.168 & 12,4 & 221.983 & 14,6 & 188.379 & 16,8 & 245.120 & 14,1 \\
\hline Ensino médio incompleto & 178.813 & 7,2 & 130.204 & 8,5 & 119.050 & 10,6 & 169.264 & 9,7 \\
\hline Ensino médio completo & 223.340 & 8,9 & 206.108 & 13,5 & 234.767 & 21,0 & 608.589 & 35,0 \\
\hline Ensino superior* & 184.747 & 7,4 & 125.263 & 8,2 & 125.000 & 11,2 & 205.252 & 11,8 \\
\hline Ignorado & 15.041 & 0,6 & 384 & 0,0 & 1 & 0,0 & 0 & 0,0 \\
\hline Total & 2.497 .322 & 100,0 & 1.523 .276 & 100,0 & 1.119 .297 & 100,0 & 1.740 .516 & 100,0 \\
\hline
\end{tabular}


Vista sob a ótica do tempo de permanência dos trabalhadores no posto de trabalho, a estrutura do emprego nos grandes estabelecimentos industriais se modificou consideravelmente na década de 1990, mas na década atual voltou a apresentar uma distribuição similar àquela do final dos anos 1980. Ou seja, durante o período de redução líquida do emprego industrial, a elevada rotatividade nos postos de trabalho em grandes estabelecimentos, uma característica estrutural do mercado de trabalho brasileiro, parece ter se reduzido, mas voltou a um patamar extremamente elevado quando o volume de admissões se recuperou ${ }^{6}$. Interessante notarmos que estamos falando de grandes estabelecimentos onde, em princípio, a preocupação com a estabilidade da mão-de-obra e o maior investimento em treinamento e qualificação é mais presente do que nas empresas de menor porte.

Em 2005, pouco mais de $1 / 4$ dos trabalhadores em grandes estabelecimentos na indústria haviam sido empregado durante o ano (Tabela 12). Se agregarmos a esse conjunto os trabalhadores que estavam no emprego havia menos de três anos, chegamos a um número superior à metade da classe operária nacional (54,0\%). Por outro lado, considerando que aqueles com pelo menos cinco anos de vínculo empregatício geralmente desfrutam de relativa estabilidade no emprego, notamos que a proporção era próximo a um terço do total (32,7\%).

Vale frisarmos também que a reestruturação produtiva iniciada a partir dos anos 1990, ao menos nesse quesito, atuou no sentido de reduzir a rotatividade nos postos de trabalho apenas enquanto predominou a resposta defensiva das grandes empresas industriais diante do acirramento da concorrência, mas que isto não provocou uma mudança definitiva nas estratégias de contratação e demissão, como parece sugerir a Tabela 12.

Tabela 12

Distribuição dos empregados nos grandes estabelecimentos industriais segundo a faixa de tempo de permanência no emprego

Brasil - 1989-2005

\begin{tabular}{|c|c|c|c|c|c|c|c|c|}
\hline Tempo no Emprego & 1989 & $\%$ & 1995 & $\%$ & 1999 & $\%$ & 2005 & $\%$ \\
\hline Até 11,9 meses & 681.684 & 27,3 & 386.109 & 25,3 & 258.468 & 23,1 & 483.640 & 27,8 \\
\hline De 12,0 a 35,9 meses & 630.173 & 25,2 & 303.880 & 19,9 & 237.894 & 21,3 & 455.488 & 26,2 \\
\hline De 36,0 a 59,9 meses & 394.573 & 15,8 & 174.914 & 11,5 & 178.120 & 15,9 & 232.501 & 13,4 \\
\hline De 60,0 a 119,9 meses & 357.177 & 14,3 & 355.408 & 23,3 & 192.021 & 17,2 & 273.280 & 15,7 \\
\hline 120 meses ou mais & 432.668 & 17,3 & 302.266 & 19,8 & 252.651 & 22,6 & 295.358 & 17,0 \\
\hline Ignorado & 1.047 & 0,0 & 699 & 0,0 & 143 & 0,0 & 249 & 0,0 \\
\hline Total & 2.497 .322 & 100,0 & 1.523 .276 & 100,0 & 1.119 .297 & $\overline{100,0}$ & 1.740 .516 & $\overline{100,0}$ \\
\hline
\end{tabular}

Fonte:RAIS/MTE. Elaboração Própria.

O Gráfico 05 demonstra que houve um aumento do tempo médio de permanência no mesmo estabelecimento, durante os anos 1990, e que na década atual registrou-se uma queda desse

\footnotetext{
${ }^{6}$ Lembremos que as informações fornecidas pela Tabela 12 não permite um cálculo preciso da taxa de rotatividade do emprego na grande empresa industrial, mas ajuda bastante a dar uma idéia do fenômeno.
} 
indicador. Diante disso, podemos supor que tal redução do tempo médio na década atual provavelmente reflete a maior proporção de empregados com menos de um ano de vínculo, num período de retomada das contratações.

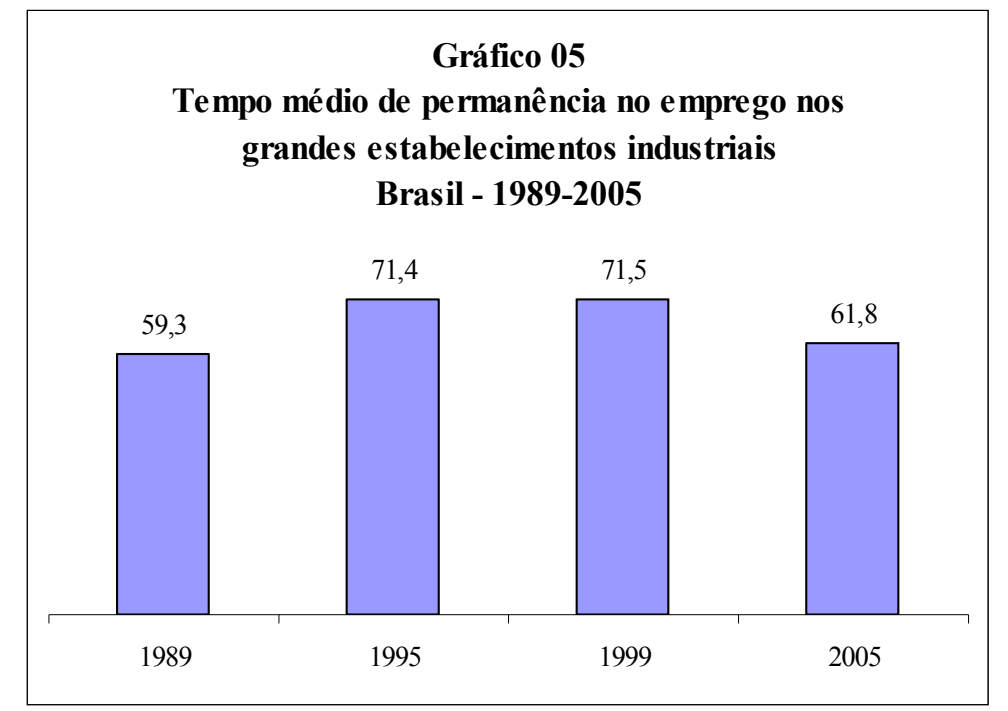

Fonte: RAIS/MTE. Elaboração Própria.

A Tabela 13 permite verificar que entre os trabalhadores sem instrução ou que não concluíram o ensino fundamental é maior a porcentagem com menos de um ano no estabelecimento, ou seja, provavelmente é maior a instabilidade do vínculo empregatício. Ainda a esse respeito, constatamos que até mesmo para os trabalhadores com maior grau de instrução que, via de regra, ocupam os postos de trabalho mais qualificados, não ocorreu melhoria significativa após a reestruturação produtiva. Por exemplo, em 1989, aproximadamente 41,7\% dos empregados com nível superior estavam no emprego havia menos de três anos; já em 2005, a quantidade de trabalhadores que se enquadravam nessa situação girava em torno de 42,2\%. Portanto, inclusive para os trabalhadores que inegavelmente pertencem ao núcleo privilegiado do mercado de trabalho, ou seja, o empregado da grande empresa industrial com maior escolaridade, não houve melhoras perceptíveis em termos do tempo de permanência na empresa. 
Tabela 13

Distribuição dos empregados nos grandes estabelecimentos industriais segundo a faixa de tempo de permanência no emprego e o grau de instrução

Brasil - 1989/2005

\begin{tabular}{|c|c|c|c|c|c|c|c|c|c|c|}
\hline \multirow{2}{*}{$\begin{array}{c}\text { Grau de instrução / } \\
\text { Tempo no emprego } \\
\text { (em meses) }\end{array}$} & \multicolumn{5}{|c|}{1989} & \multicolumn{5}{|c|}{2005} \\
\hline & Até 11,9 & \begin{tabular}{|c|} 
De 12,0 a \\
35,9 \\
\end{tabular} & $\begin{array}{c}\text { De 36,0 } \\
\text { a } 59,9 \\
\end{array}$ & \begin{tabular}{|c|} 
De 60,0 a \\
119,9 \\
\end{tabular} & $\begin{array}{l}120 \text { ou } \\
\text { mais }\end{array}$ & Até 11,9 & $\begin{array}{c}\text { De } 12,0 \\
\text { a } 35,9 \\
\end{array}$ & $\begin{array}{c}\text { De 36,0 } \\
\text { a 59,9 } \\
\end{array}$ & \begin{tabular}{|c|} 
De 60,0 a \\
119,9 \\
\end{tabular} & $\begin{array}{c}120 \text { ou } \\
\text { mais }\end{array}$ \\
\hline Analfabeto & $29,8 \%$ & $22,2 \%$ & $11,5 \%$ & $15,6 \%$ & $20,6 \%$ & $53,2 \%$ & $15,6 \%$ & $9,7 \%$ & $9,0 \%$ & $12,6 \%$ \\
\hline $\begin{array}{l}\text { Ensino fundamental } \\
\text { incompleto }\end{array}$ & $28,3 \%$ & $25,0 \%$ & $15,2 \%$ & $14,2 \%$ & $17,3 \%$ & $32,6 \%$ & $22,4 \%$ & $12,7 \%$ & $13,8 \%$ & $18,5 \%$ \\
\hline $\begin{array}{l}\text { Ensino fundamental } \\
\text { completo }\end{array}$ & $30,3 \%$ & $26,4 \%$ & $17,1 \%$ & $13,0 \%$ & $13,2 \%$ & $23,4 \%$ & $26,5 \%$ & $13,9 \%$ & $17,2 \%$ & $19,0 \%$ \\
\hline $\begin{array}{l}\text { Ensino médio } \\
\text { incompleto }\end{array}$ & $27,9 \%$ & $26,3 \%$ & $18,3 \%$ & $13,2 \%$ & $14,2 \%$ & $29,1 \%$ & $30,2 \%$ & $14,2 \%$ & $15,5 \%$ & $11,0 \%$ \\
\hline $\begin{array}{l}\text { Ensino médio } \\
\text { completo }\end{array}$ & $24,0 \%$ & $25,4 \%$ & $18,1 \%$ & $15,7 \%$ & $16,9 \%$ & $26,2 \%$ & $30,1 \%$ & $13,6 \%$ & $15,9 \%$ & $14,1 \%$ \\
\hline Superior* & $17,8 \%$ & $23,9 \%$ & $15,6 \%$ & $16,2 \%$ & $26,4 \%$ & $20,7 \%$ & $21,5 \%$ & $13,6 \%$ & $19,1 \%$ & $25,1 \%$ \\
\hline Total & $27,3 \%$ & $25,2 \%$ & $15,8 \%$ & $14,3 \%$ & $17,3 \%$ & $27,8 \%$ & $26,2 \%$ & $13,4 \%$ & $15,7 \%$ & $17,0 \%$ \\
\hline
\end{tabular}

Fonte:RAIS/MTE. Elaboração Própria.

* completo e incompleto

Obs.: O resultado das linhas pode não totalizar $100 \%$ uma vez que os ignorados foram excluídos.

No que se refere ao tempo de trabalho (jornada semanal), percebemos que a grande maioria dos trabalhadores dos estabelecimentos de grande porte na indústria de transformação, mais de $85,0 \%$, exerce semanalmente uma jornada de trabalho legal superior a 40 horas. Lembremos que embora a prática das horas extras seja generalizada no mercado de trabalho brasileiro, a RAIS só permite examinar a jornada contratual, o que torna impossível uma percepção mais acurada da jornada de trabalho efetivamente exercida no âmbito das grandes empresas industriais (Tabela 14).

Tabela 14

Distribuição dos empregados nos grandes estabelecimentos industriais segundo a faixa de horas contratuais

Brasil - 1995-2005

\begin{tabular}{|l|r|r|r|r|r|r|}
\hline Faixa de Horas Contratuais & \multicolumn{1}{|c|}{$\mathbf{1 9 9 5}$} & $\mathbf{\%}$ & \multicolumn{1}{|c|}{$\mathbf{1 9 9 9}$} & $\mathbf{\%}$ & $\mathbf{2 0 0 5}$ & \multicolumn{1}{c|}{$\%$} \\
\hline Até 20 horas semanais & 3.820 & 0,3 & 1.104 & 0,1 & 3.212 & 0,2 \\
\hline De 21 a 30 horas semanais & 16.350 & 1,1 & 5.829 & 0,5 & 10.427 & 0,6 \\
\hline De 31 a 40 horas semanais & 133.820 & 8,8 & 129.290 & 11,6 & 189.299 & 10,9 \\
\hline De 41 a 44 horas semanais & 1.369 .264 & 89,9 & 983.072 & 87,8 & 1.537 .578 & 88,3 \\
\hline Ignorado & 22 & 0,0 & 2 & 0,0 & 0 & 0,0 \\
\hline Total & 1.523 .276 & 100,0 & 1.119 .297 & 100,0 & 1.740 .516 & 100,0 \\
\hline
\end{tabular}

Fonte:RAIS/MTE. Elaboração Própria.

Um aspecto fundamental para a compreensão das transformações do emprego na grande empresa industrial reside no comportamento dos salários recebidos pelos trabalhadores ao longo desse período de hegemonia do pensamento econômico neoliberal e de implantação da reestruturação produtiva. Em tese, podemos imaginar que a terceirização de várias funções antes exercidas pelas grandes empresas e o enxugamento do quadro de pessoal teriam o efeito de ampliar o salário médio dos empregados que permanecem contratados (inclusive porque são melhor 
qualificados). Por outro lado, a prática de substituir trabalhadores melhor remunerados por trabalhadores mais jovens e com salários menores, assim como a adoção de salários flexíveis (de acordo com a produtividade e as vendas), podem exercer o efeito inverso. Vejamos o que dizem os dados empíricos sobre as remunerações registradas no contrato de trabalho.

No Gráfico 06, podemos observar que o salário médio real nos grandes estabelecimentos industriais registrou um crescimento na segunda metade da década passada. Contudo, nos anos 2000, o movimento se inverteu e o salário médio na grande empresa industrial apresentou um declínio significativo. Por exemplo, entre 1999 e 2005 houve uma redução do salário real médio de aproximadamente $5,0 \%{ }^{7}$.

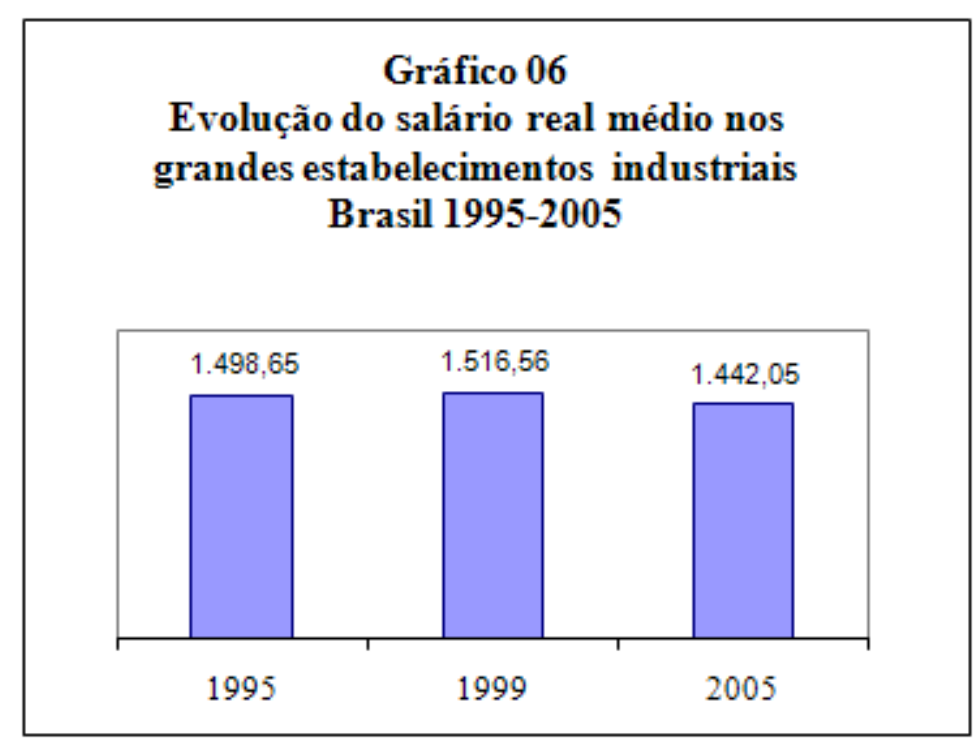

Fonte: RAIS/MTE. Elaboração Própria.

Deflator $=$ INPC.

Além da queda salarial verificada na presente década, o que os dados demonstram é que a dinâmica da grande empresa industrial a partir de meados dos anos 1990, influenciada em grande medida pela guerra fiscal entre as unidades da Federação, não trouxe os benefícios esperados em termos de uma maior homogeneização salarial entre as diversas regiões brasileiras. Pelo contrário, o que se viu foi uma manutenção e até mesmo uma ampliação da distância entre o salário contratual no sudeste e nas demais regiões (Tabela 15).

\footnotetext{
${ }^{7}$ Provavelmente, o salário real médio nos grandes estabelecimentos situava-se, em 1989, num patamar bastante acima do verificado a partir dos anos 1990. No entanto, o índice deflator disponível não é confiável devido ao total descontrole dos preços naquele ano. Por conta disso, optamos por não incluir o ano de 1989 nas séries históricas do comportamento salarial apresentadas neste estudo.
} 
Tabela 15

Evolução do salário real médio nos grandes estabelecimentos industriais de acordo com a região natural

Brasil 1995/2005

\begin{tabular}{|l|r|r|r|r|r|r|}
\hline \multirow{2}{*}{ Região Natural } & \multicolumn{2}{|c|}{1995} & \multicolumn{2}{|c|}{1999} & \multicolumn{2}{|c|}{2005} \\
\cline { 2 - 7 } & Rend. médio & $\begin{array}{l}\text { \% em relação } \\
\text { ao sudeste }\end{array}$ & Rend. médio & $\begin{array}{l}\% \text { em relação } \\
\text { ao sudeste }\end{array}$ & Rend. médio & $\begin{array}{l}\% \text { em relação } \\
\text { ao sudeste }\end{array}$ \\
\hline Norte & $1.181,9$ & $62,1 \%$ & $1.563,7$ & $79,1 \%$ & $1.190,4$ & $60,5 \%$ \\
\hline Nordeste & 641,0 & $33,7 \%$ & 608,5 & $30,8 \%$ & 675,7 & $34,3 \%$ \\
\hline Sudeste & $1.904,3$ & $100,0 \%$ & $1.976,2$ & $100,0 \%$ & $1.967,9$ & $100,0 \%$ \\
\hline Sul & $1.067,0$ & $56,0 \%$ & $1.128,7$ & $57,1 \%$ & $1.111,1$ & $56,5 \%$ \\
\hline Centro-Oeste & 937,3 & $49,2 \%$ & 864,5 & $43,7 \%$ & 795,7 & $40,4 \%$ \\
\hline Total & $1.498,6$ & - & $1.516,6$ & - & $1.442,1$ & - \\
\hline
\end{tabular}

Fonte: RAIS/MTE. Elaboração Própria.

Deflator $=$ INPC.

Podemos visualizar ainda o comportamento na política de remuneração das grandes empresas industriais entre 1995 e 2005 por subsetor de atividade econômica. Assim sendo, na segunda metade da década passada, o comportamento do salário real médio nos grandes estabelecimentos da indústria apresentou-se de modo bastante heterogêneo, com subsetores registrando ampliação e outros subsetores declínio. Na primeira metade da década atual, por sua vez, a política de remuneração praticada pelas grandes empresas da indústria de transformação permaneceu bastante diferenciada por subsetor. Porém, analisando o intervalo de uma década (1995-2005) percebe-se que a tendência geral foi de rebaixamento salarial em praticamente todos os subsetores, com exceção da indústria de produtos minerais não-metálicos, da indústria do papel, papelão, editorial e gráfica e da indústria química de produtos farmacêuticos, veterinários e perfumaria (Tabela 16). 
Tabela 16

Evolução do salário real médio nos grandes estabelecimentos industriais de acordo com o subsetor de atividade econômica

Brasil 1995-2005

\begin{tabular}{|c|c|c|c|}
\hline Subsetor de atividade econômica & 1995 & 1999 & 2005 \\
\hline Indústria de produtos minerais nao metálicos & $1.335,63$ & $1.513,03$ & $1.513,15$ \\
\hline Indústria metalúrgica & $2.052,54$ & $2.008,45$ & $2.043,63$ \\
\hline Indústria mecânica & $1.854,32$ & $1.805,41$ & $1.832,80$ \\
\hline Indústria do material elétrico e de comunicaçoes & $1.748,73$ & $1.879,75$ & $1.531,57$ \\
\hline Indústria do material de transporte & $2.534,18$ & $2.462,86$ & $2.453,90$ \\
\hline Indústria da madeira e do mobiliário & 941,05 & 842,83 & 931,11 \\
\hline Indústria do papel, papelao, editorial e gráfica & $1.987,70$ & $2.509,05$ & $2.233,76$ \\
\hline Ind. da borracha, fumo, couros, peles, similares, ind. diversas & $1.687,60$ & $1.763,78$ & $1.629,93$ \\
\hline Ind. química de produtos farmacêuticos, veterinários, perfumaria, ... & $2.445,26$ & $2.432,99$ & $3.085,17$ \\
\hline Indústria têxtil do vestuário e artefatos de tecidos & 916,97 & 839,23 & 829,46 \\
\hline Indústria de calçados & 637,25 & 563,41 & 586,60 \\
\hline Indústria de produtos alimentícios, bebidas e álcool etílico & 828,05 & 869,78 & 808,11 \\
\hline Total & $1.498,65$ & $1.516,56$ & $1.442,05$ \\
\hline
\end{tabular}

Fonte:RAIS/MTE. Elaboração Própria.

Deflator $=$ INPC.

Finalmente, passando para a análise da formas de contratação dos trabalhadores, seria de esperar, dada a hegemonia do discurso da flexibilidade no meio empresarial, que as modalidades de contrato de trabalho criadas e/ou modificadas ao longo desse período (trabalho por tempo determinado, em tempo parcial, temporário, primeiro emprego, entre outros) ganhariam uma importância crescente no mercado de trabalho brasileiro. Ao menos no que toca aos grandes estabelecimentos industriais, isso não ocorreu.

Ao olharmos os dados abaixo, verificamos que os contratos de trabalho dito flexíveis, ou seja, todos aqueles diferentes dos regidos pela CLT por prazo indeterminado ou por estatuto próprio, não representavam mais do que 3,0\% das formas de contratação realizada pelos grandes estabelecimentos industriais no ano de 2005 (Tabela 17).

No nosso entender, isso nos mostra que a elevada flexibilidade existente no chamado contrato de trabalho padrão - vide a alta rotatividade da mão-de-obra - não cria os incentivos necessários a ponto de tornar atrativo para os empresários a adoção generalizada das novas modalidades de contratação da força de trabalho no Brasil. Além disso, o que pode ter ocorrido, paralelamente, é que as grandes empresas têm deixado a cargo das pequenas e médias empresas terceirizadas a maior parte dos chamados contratos de trabalho flexíveis. 
Tabela 17

Distribuição dos empregados nos grandes estabelecimentos industriais segundo o tipo de vínculo Brasil - 1989-2005

\begin{tabular}{|c|c|c|c|c|c|c|c|c|}
\hline Tipo de Vínculo & 1989 & $\%$ & 1995 & $\%$ & 1999 & $\%$ & 2005 & $\%$ \\
\hline Contrato de trabalho padrão* & 2.434 .875 & 97,5 & 1.491 .257 & 97,9 & 1.089 .604 & 97,3 & 1.685 .533 & 96,8 \\
\hline Contrato de trabalho flexível** & 47.126 & 1,9 & 32.009 & 2,1 & 29.693 & 2,7 & 54.983 & 3,2 \\
\hline Ignorado & 15.321 & 0,6 & 10 & 0,0 & $\begin{array}{l}0 \\
\end{array}$ & 0,0 & 0 & \\
\hline Total & 2.497 .322 & 100,0 & 1.523 .276 & 100,0 & 1.119 .297 & 100,0 & 1.740 .516 & 100,0 \\
\hline
\end{tabular}

Fonte:RAIS/MTE. Elaboração Própria.

* Trabalhador urbano vinculado a empregador pessoa jurídica por contrato de trabalho regido pela CLT, por prazo indeterminado, Trabalhador rural vinculado a empregador pessoa juridica por contrato de trabalho regido pela Lei nr. 5.889/73, por prazo indeterminado, Servidor regido pelo Regime Jurídico Único (federal, estadual e municipal) e militar, vinculado a Regime Próprio de Previdência e Servidor regido pelo regime Jurídico Único (federal, estadual e municipal) e militar, vinculado ao Regime Geral de Previdência Social.

** Demais formas de contratação legal que não foram citadas anteriormente.

\section{Considerações Finais}

O diagnóstico feito possibilita levantarmos algumas questões importantes a título de conclusão. Em primeiro lugar, podemos perceber dois períodos relativamente distintos no que tange ao comportamento do emprego nos grandes estabelecimentos industriais no intervalo de tempo analisado. Nos anos 1990, constatamos uma perda na participação relativa da indústria de transformação no emprego formal, grande parte em decorrência do enxugamento do emprego ligado aos estabelecimentos de grande porte. Tal comportamento foi fruto, de um lado, dos constrangimentos impostos por uma economia de baixo crescimento econômico, e, de outro, dos impactos da reestruturação produtiva poupadora de mão-de-obra que, além de desempregar uma parte da força de trabalho, terceiriza para os estabelecimentos de menor porte atividades até então realizadas dentro da grande empresa.

Já na década seguinte, a tendência verificada anteriormente sofreu uma inflexão. A participação relativa da indústria de transformação no emprego formal se estabiliza, ao passo que os grandes estabelecimentos do setor voltam a gerar postos de trabalho com vínculo de emprego formalizado em ritmo superior aos pequenos e aos médios estabelecimentos. Por isso mesmo, a grande empresa volta a ganhar uma maior relevância em termos de participação no mercado de trabalho formal da indústria na primeira metade dos anos 2000. Nesse cenário, o que os dados parecem indicar é que o processo de reestruturação produtiva assentado na redução do contingente da força de trabalho tem chegado ao seu limite nas grandes empresas e que um ambiente de maior aquecimento da demanda agregada proporcionado pelo aumento acelerado das exportações brasileiras gerou novo dinamismo e novas perspectivas para o emprego industrial.

Diante desse quadro, foi possível observar uma redução da quantidade de estabelecimentos considerados de grande porte na década de 1990 paralelamente a uma tendência de redução do tamanho médio destes estabelecimentos. No entanto, a partir dos anos 2000 o movimento registrado 
é o inverso: um aumento da quantidade dos grandes estabelecimentos na indústria acompanhado do aumento do seu tamanho médio.

Em termos da distribuição regional das grandes empresas, percebemos que de 1989 a 2005 ocorreu um movimento importante de desconcentração produtiva no qual a região sudeste do país perdeu participação expressiva tanto em termos da quantidade dos estabelecimentos de grande porte quanto em termos do número de trabalhadores vinculados a estes estabelecimentos. A principal beneficiada por esse movimento foi a região sul, que nesse intervalo de tempo aumentou de modo contínuo a sua participação relativa no total dos grandes estabelecimentos industriais, bem como dos trabalhadores ligados a elas. A região nordeste, em particular, registrou um ganho de participação relativa no número de estabelecimentos de grande porte durante os anos 1990, porém, na primeira metade dos anos 2000 ocorreu uma redução importante que praticamente anulou o crescimento alcançado na década anterior. Já em termos de trabalhadores em grandes empresas industriais, o nordeste contabilizou um crescimento ininterrupto entre 1989 e 2005, o que sugere que as grandes empresas localizadas nesta região são mais intensivas em mão-de-obra comparativamente às demais regiões.

Além disso, é importante destacar que a partir dos anos 1990, em todas as regiões brasileiras outros espaços urbanos têm aumentado de importância em termos de localização e de trabalhadores nas grandes empresas industriais vis-à-vis às regiões metropolitanas mais conhecidas.

Em termos regionais, portanto, o investimento representado pelas grandes empresas industriais tem privilegiado as regiões menos tradicionais do ponto de vista da produção manufatureira, muito por conta das pressões impostas por uma reestruturação produtiva que busca reduzir custos - e nesse cenário o custo do trabalho tem um peso muito importante - associada a um aumento da concorrência interna advinda com a abertura econômica.

No que se refere aos impactos causados pela reestruturação da grande empresa industrial entre 1989 e 2005 sobre o perfil da força de trabalho, os resultados apontam mudanças importantes, mas também continuidade de velhas características. Não se alterou a predominância do sexo masculino na ocupação dos postos de trabalho formais. Ademais, as mulheres que trabalham nas grandes empresas ainda encontram uma grande dificuldade de ascender profissionalmente visto que boa parte dos cargos de direção e gerência ainda é ocupada pelos trabalhadores masculinos.

Importa ressaltar que houve uma melhora substancial do grau de escolarização dos trabalhadores das grandes empresas do setor industrial, ao passo que não existem indícios de que tenha havido um aumento do tempo de permanência dos trabalhadores no emprego. E ficou evidente que os salários reais registrados no contrato de trabalho têm apresentado uma tendência declinante nos anos mais recentes. Por último, registramos mais uma vez a baixa participação que 
os contratos flexíveis têm frente ao contrato de trabalho padrão, o que se explica em grande medida pelo grande livre arbítrio permitido ao empregador pela legislação trabalhista vigente.

Em suma, as transformações que vêm ocorrendo desde o início da década passada não têm, até o presente momento, se traduzido em melhores condições de emprego e renda para a maioria da classe operária nacional, nem muito menos contribuído para uma maior eqüidade salarial entre as diversas regiões brasileiras. Pelo contrário, os dados disponíveis têm sugerido que, em tempos de concorrência voraz, em que pese o menor peso do custo do trabalho nas grandes empresas, estas têm procurado ganhar melhores condições de competitividade à custa do elo mais frágil, qual seja, a classe operária, inclusive se beneficiando das gritantes disparidades regionais em termo salariais que continuam caracterizando a economia brasileira.

\begin{abstract}
The present article intends to discuss the impacts of the productive restructuring on the job level and the wages in the great industrial companies, as well as verifying if it changed the regional distribution of the industrial job and the employees' profile of the section. In that sense, two quite different periods can be visualized. In the decade of 1990 there was a loss in the relative participation of the process industry in the formal job, in consequence, above all, of the reduction promoted by the establishments of great size. In the years 2000, there was an inflection: the great establishments of the industry generate employment again and the participation of the section is stabilized. In regional terms, the investment of the great companies has been privileging less traditional areas in search of fiscal benefits and reduction in the cost of the work, being the south the great beneficiary of that movement of industrial distract in the years 1990. In what it refers to the impacts caused by the restructuring of the great industrial company on the profile of the workforce, the results point important changes, but also continuity of old characteristics. In short, the transformations that are happening don't have if translated in better job conditions and income for most of the national working class, nor contributed to a larger salary justness among the several Brazilian areas.
\end{abstract}

Key-words: productive restructuring; job; great company.

\title{
Referências Bibliográficas
}

ALVES, Giovanni (2000). O novo (e precário) mundo do trabalho: reestruturação produtiva e crise do sindicalismo. São Paulo: Boitempo.

ARBIX, Glauco (2000). Guerra fiscal e competição intermunicipal por novos investimentos no setor automotivo brasileiro. Dados, Rio de Janeiro, v. 43, n. 1. Disponível em: <http://www.scielo.br>. Acesso em: 18 Nov. 2006. 
BALTAR, Paulo; KREIN, José Dari e MORETTO, Amilton (2006). O emprego formal nos anos recentes. Carta Social e do Trabalho, $\mathrm{n}^{\circ}$ 3. jan./abr. 2006. Obtido em: <http://www.eco.unicamp.br>. Acesso em: 14/11/2006.

CANO, Wilson (1997). Concentração e desconcentração econômica regional no Brasil: 1970/95. Economia e sociedade. Campinas, $\mathrm{n}^{\circ} 08$, p. 101-141.

CARLEIAL, Liana (2004). Subdesenvolvimento globalizado: a resultante das escolhas da políticas econômicas brasileira nos anos noventa. Revista paranaense de desenvolvimento econômico, Curitiba, no 106, p. 7-28.

FARHI, Maryse (2004). Metas de inflação e o medo de crescer. Política econômica em foco, $\mathrm{n}^{\circ} 4$. Obtido em: $<$ http://www.eco.unicamp.br>. Acesso em: 14/11/2006.

GONÇALVES, Reinaldo (1999). Globalização e desnacionalização. São Paulo: Paz e terra.

MARQUES, Ivan (2002). O Brasil e a abertura dos mercados: o trabalho em questão. Rio de Janeiro: Contraponto.

OLIVEIRA, Tiago (2007). Transformações Recentes do Emprego na Grande Empresa Industrial no Brasil. Campinas: Unicamp. (Dissertação, Mestrado em Desenvolvimento Econômico).

PACHECO, Carlos (1996). Desconcentração econômica e fragmentação da economia nacional. Economia e Sociedade, Campinas, $n^{\circ} 06$, p. 113-140.

(1999). Novos padrões de localização industrial? Tendências recentes dos indicadores da produção e do investimento industrial. Texto para discussão n ${ }^{\circ}$ 633. Brasília: IPEA.

PORTER, Michael (1986). Estratégia competitiva: técnicas para análise de indústrias e da concorrência. Rio de Janeiro: Campus.

(org.) (1999). Competição: estratégias competitivas essenciais. Rio de Janeiro: Campus.

(1999). Competindo além das localidades: ampliando a vantagem competitiva através de uma estratégia global. In: PORTER, Michael (org.) (1999). Competição: estratégias competitivas essenciais. Rio de Janeiro: Campus.

PRONI, M. W. e HENRIQUE, W. (orgs.) (2003). Trabalho, mercado e sociedade: o Brasil nos anos 90. São Paulo: Ed. Unesp.

PRONI, Marcelo W. e POCHMANN, Marcio (2006). Globalização, neoliberalismo e reestruturação produtiva. In: DEDECCA, C. S. \& PRONI, M. W. (orgs.) Economia e proteção social: textos para estudo dirigido. Campinas/SP: Unicamp.IE; Brasília/DF: MTE; Unitrabalho.

\section{Dados completos dos autores}

\section{Tiago Oliveira}

Departamento Intersindical de Estatística e Estudos Sócio-Econômicos - DIEESE

Assessor Técnico

SQN 214 Bloco E Ap. 510

CEP: 70873-050 Brasília - DF

(61) $3345-8855$ e $8407-9973$

\section{Marcelo Weishaupt Proni}

Universidade Estadual de Campinas - Unicamp

Professor

Universidade Estadual de Campinas - Instituto de Economia. Caixa Postal: 6135. 
Campinas-SP. CEP: 13.083-857

(19) $3521-5807$.

Recebido para publicação em: 16/07/07 Aceito para publicação em:10/08/07 